\title{
Integrated petrographic and geochemical analysis of the Langobard age pottery of Szólád, Western Hungary
}

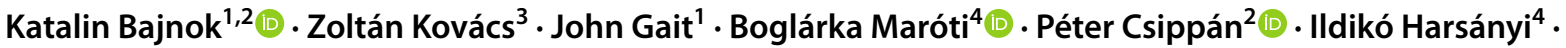 \\ Dénes Párkányi ${ }^{4} \cdot$ Péter Skriba $^{5} \cdot$ Daniel Winger $^{6} \cdot$ Uta von Freeden $^{7} \cdot$ Tivadar Vida $^{2,8}{ }^{(\mathbb{D}} \cdot$ György Szakmány $^{3}$
}

Received: 9 August 2021 / Accepted: 23 October 2021 / Published online: 27 December 2021

(c) The Author(s) 2021, corrected publication 2022

\begin{abstract}
This study presents the results of the petrographic and geochemical analyses of the entire pottery assemblage discovered at the sixth-century (AD) cemetery of Szólád, Western Hungary, associated with the Langobard era in the territory of the former Roman province of Pannonia. Szólád is one of the most prominent archaeological sites of this period, where prior studies have shown that the cemetery was used for ca. one or two generations by a migrating group of diverse genetic background. The present work is the first integrated typological and archaeological science pottery analysis from the early migration period (fifth to sixth century) Hungary. We applied polarising light optical microscopy (OM), prompt gamma activation analysis (PGAA), and neutron activation analysis (NAA) on all samples and, additionally, scanning electron microscopy equipped with energy dispersive spectrometry (SEM-EDS) on one selected sample. One main fabric group with three subgroups were defined by OM, to which the majority of the samples belong. This fabric group was characterised by aplastic inclusions derived from a carbonate-cemented sandstone typical of the environs of Szólád; therefore, the vessels of this fabric group appear to have been produced locally. The remaining four samples display a variety of unique, ungrouped, fabrics (loners) indicative of different recipes and/or the presence of pottery originating from outside of the region. Our study concludes that the community associated with the cemetery favoured burying pots with the deceased that stylistically resembled archaic "Elbe Germanic" traditions, but which were in fact made locally. However, in some cases, relationships with more distant territories and cultural traditions are also represented.
\end{abstract}

Keywords Migration period $\cdot$ Langobards $\cdot$ Ceramic petrography $\cdot$ PGAA $\cdot$ NAA $\cdot$ SEM-EDS

Katalin Bajnok

bajnok.katalin@ek-cer.hu

1 Neutron Spectroscopy Department, Centre for Energy Research, ELKH, Budapest, Hungary

2 Institute of Archaeological Sciences, Eötvös Loránd University, Budapest, Hungary

3 Department of Petrology and Geochemistry, Eötvös Loránd University, Budapest, Hungary

4 Nuclear Analysis and Radiography Department, Centre for Energy Research, ELKH, Budapest, Hungary

5 Archaeological Heritage Protection Directorate, Hungarian National Museum, Budapest, Hungary

6 Heinrich Schliemann-Institute of Ancient Studies, University of Rostock, Rostock, Germany

7 Frankfurt am Main, Germany

8 Institute of Archaeology, Research Centre for the Humanities, ELKH, Budapest, Hungary

\section{Introduction}

\section{Archaeological and historical context}

The fourth to seventh centuries AD represent a dynamic, politically unstable period in the former Roman province of Pannonia (present-day territory of Transdanubia, Western Hungary, Fig. 1). As in other former provinces, the collapse of the Western Roman Empire was accompanied by major sociocultural and economic changes in the Pannonian territories as well. These centuries were dominated by increasing migration of several barbarian (i.e. non-Romanised) peoples arriving from north and east of the Danube limes, after the province gradually lost its political and military importance, and the imperial Roman public administration relinquished the province. In the $440 \mathrm{~s}$, the territory was occupied by the Huns and remained under Hunnic rule until Attila's death in 453 (Vida 2011; Koncz 2019). While, according to historical sources, 


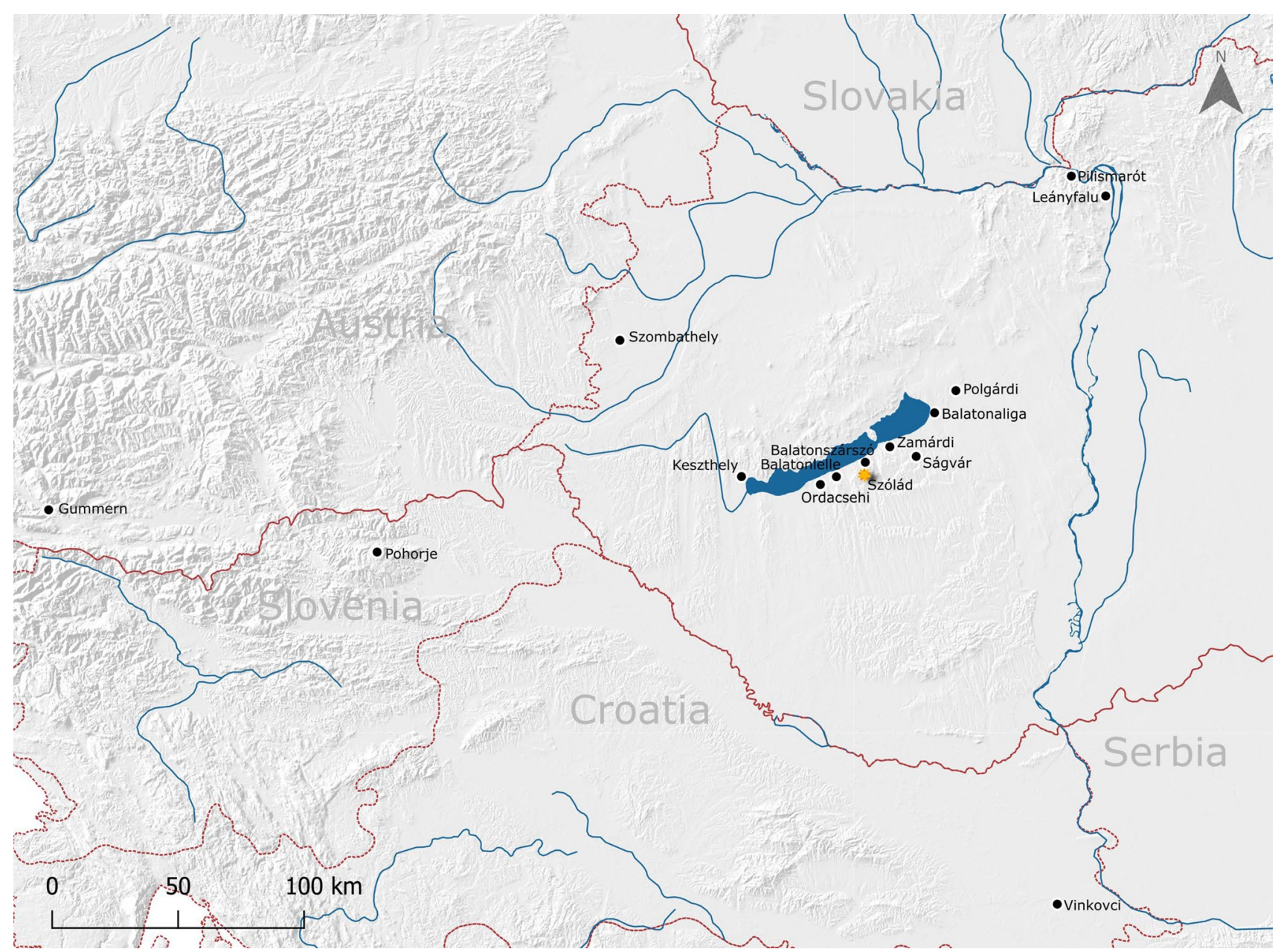

Fig. 1 Location of Szólád and other contemporaneous archaeological sites mentioned in this paper

the Romanised administrative elite left the province during the first half of the fifth century, archaeological records show that late antique "elements" (people, traditions, customs) persisted for centuries despite the intensive migration. How this new structure, a melting pot of "locals" and "settlers", worked out in practice, how their traditions and material culture affected each other, and how those can be plotted in a wider European context have been in the focus of archaeological and historical research in the last decades (Goetz et al. 2003; Wickham 2005; Heather 2007; Vida 2009; Hakenbeck 2011), referring to this period in short as the great migration period.

From historical sources, the sixth century in Pannonia can be characterised by the political dominance of a Germanic tribe, the Langobards (also described as Lombards, Longobardi, or Longbeards). First mentioned in texts by Roman historian Velleius Paterculus in the first century AD, they are conventionally thought to originate from east of the lower Elbe River. Their previous territory before the Pannonian expansion was between the mid-fifth and mid-sixth centuries in the vicinity of the North Bohemian Basin and then Moravia, from where they gradually migrated and occupied first the northern, then the southern part of the former Pannonian province. Their Pannonian phase is dated between the 510s and 568 (Koncz 2015), when they fled to Italy, to the territory now known as Lombardy, led by their king, Alboin. Their kingdom, expanded to most of present-day Italy, lasted until 774 AD. However, during the Langobard period, Pannonia was under the political control of the Langobard king, it is assumed that in fact the population comprised several barbarian peoples and remaining local Roman provincials (Rácz and Vida 2018). Therefore, in this paper, the authors do not aim at defining Langobard ethnicity, which is a subjective identity, but rather use this term "Langobard" to describe a distinct period in the history of Pannonia which is connected to the dominance of a political organisation. 


\section{The sixth-century cemetery of Szólád}

This study presents the analysis of the pottery excavated from the cemetery of Szólád (Fig. 1), dated to the Langobard period, the middle third of the sixth century AD (Freeden and Vida 2007; Vida 2008; Freeden 2008; Vida et al. 2017; Freeden and Winger 2018; Freeden et al. 2020). The cemetery was excavated between 2005 and 2010 by Tivadar Vida, Uta von Freeden, and Daniel Winger, where 45 burials have been unearthed. Based on the previous investigations (Alt et al. 2014; Amorim et al. 2018), the cemetery was used for about 20-30 years (ca. 1-2 generations). The individuals buried at Szólád belonged to a migrating group where adults had diverse background with regard to the place where they grew up, while most children were born in the vicinity of Szólád (Alt et al. 2014). The majority of the deceased had dominantly central/northern European genetic ancestry, while about a quarter of the population were of southern European origin (Amorim et al. 2018). Most of the grave goods and funerary practices display similarities mainly with those of south and central Germany, but also Lower Austria/ south Moravia; however, late antique elements in the material culture (especially burial customs, jewellery, and some vessel types) are also present.

\section{The pottery of Szólád}

In the cemetery, altogether 19 complete vessels and one potsherd were uncovered. The sample code names in Table 1 refer to the grave numbering. Less than half of the graves contained pots, and when they did, usually one vessel was present, except for graves 10,11, and 13. The two main vessel types are the Rippen- und Buckelschale ("humped" bowl, henceforward: deep bowls) and the Kumpf (closed hole-mouth jar, also known as swebische Topf).

The deep bowls $(n=9)$ are always necked, with near equal mouth and bottom diameter and widening and closing body in between, having vertical or slightly out-curving rim and biconical or "S"-shaped profile. Their surface is burnished or smoothed, and they are often decorated with incised line decoration (Stichdekor, Sz 1, Sz 3, Sz 11/1, Sz 18, Sz 22 ), typically horizontal line bands on the neck and vertical line bands on the body. In some cases, inclined fluting (Schrägkannelur, Sz 1, Sz 10/1) or dimple decoration (Dellenverzierung, $\mathrm{Sz} \mathrm{18)}$ is also present. These vessels were all formed by hand but are carefully manufactured; their colour varies from light brown to greyish brown, usually unevenly fired. This type represents an archaic shape that was widespread among barbarian peoples from the first third of the fifth century along the Danube in south Moravia and Lower Austria, but the archetype itself can be dated back to the first to second centuries in the surroundings of the Elbe area (Bóna 1956; Bóna and Horváth 2009; Tejral 1985, 2005 ,
2011; Werner 1962). Three bowls of this vessel type from Szólád display lower quality in manufacturing ( $\mathrm{Sz} 23, \mathrm{Sz}$ $31, \mathrm{Sz} 45)$. Their shapes are more irregular, and they are not decorated at all; therefore, they can be considered a simpler variant within this type.

The closed hole-mouth jars $(n=8)$ represent one of the simplest and most generic shapes of pottery connected to some barbarian peoples. It was observed at sites associated with the Quadi as early as the second to third centuries, and as with the deep bowls, they are also thought to be one of the main archaic types originating from the Elbe region. Connected to the Langobard migration, closed hole-mouth jars are found abundantly in Lower Austria and south Moravia (it represents approximately $70 \%$ of the funerary ceramics). However, they are also present in the Pannonian phase as well, but in gradually decreasing quantities (Tejral, 2005; Bóna and Horváth 2009). In Szólád, this type is always hand-made, but their quality varies with regard to the evenness of the body or the surface. Except for one vessel (Sz 15), this type was not decorated at all; their colours are usually light brown to dark brown. Both the bowls and the holemouth jars varied in size, which suggests that they were used for different purposes, i.e. they were not associated with a single function, but rather they can be interpreted as a spectrum, or set of vessels representing a certain style.

The Thuringian cup (Sz 13/1) is one of the most unique finds of the cemetery. The production of this wheel-thrown, pattern burnished vessel type is associated with the central German-north-western Bohemian region (former Thuringian Kingdom) and can be dated between the $520 \mathrm{~s}$ and $570 \mathrm{~s}$. It is important to emphasise that this term refers to a special vessel type, and does not intend to express a cultural or ethnic identity. Mostly recovered from burials, so far no pottery workshops of the Thuringian vessels are known; however, given the distribution area, a large-scale production centre is anticipated, where this shape was developed as a wheelthrown version of the above-described hand-shaped, deep bowl archetype. Wheel-thrown pottery production of this barbarian vessel type is not typical in this milieu; therefore, it has been assumed that such production has roots in late Roman pottery-making practices adapted to a "more Germanic" taste (Droberjar 2008). The vessel from grave 13 excavated in Szólád is the first known specimen found in Pannonia. Also in this grave was found a potsherd with

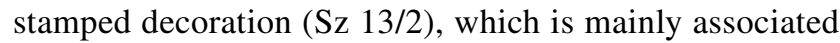
with "bag-shaped" (beutelförmig in German literature) or "pear shaped" (körte formájú, according to Hungarian terminology) stamped jars. This vessel type was thought to be developed in south Pannonian workshops and was widespread contemporaneously in the territory of the Langobard and Gepid Kingdoms (Werner 1962; Bóna and B. Horváth, 2009) and, later, in the Italian Lombard Kingdom, became one of the most widely used types (Hessen 1968). 
Table 1 Summary of the vessels of Szólád, indicating the sample code name, style/typology, and petro-fabric group (illustrations: Péter Skriba)

\begin{tabular}{|c|c|c|c|}
\hline Sample name & Style/Typology & Fabric group & Illustration \\
\hline Sz 1 & $\begin{array}{l}\text { Biconical deep bowl (Schale) with low- } \\
\text { burnish surface and askew fluting and } \\
\text { incised decoration }\end{array}$ & $1 \mathrm{~A}$ & \\
\hline Sz 2 & $\begin{array}{l}\text { Undecorated, closed hole-mouth } \\
\text { small jar (Kumpf) }\end{array}$ & $1 B$ & \\
\hline Sz 3 & $\begin{array}{l}\text { Biconical deep cup (Schale) with low- } \\
\text { burnish surface and incised decoration }\end{array}$ & $1 \mathrm{~A}$ & \\
\hline Sz 10/1 & $\begin{array}{l}\text { 'S' profile deep bowl (Schale) with } \\
\text { low-burnish surface and inclined } \\
\text { fluting decoration }\end{array}$ & $1 \mathrm{~A}$ & \\
\hline Sz 10/2 & $\begin{array}{l}\text { Undecorated, closed hole-mouth cup } \\
\text { (Kumpf) }\end{array}$ & $1 B$ & \\
\hline Sz 11/1 & $\begin{array}{l}\text { 'S' profile deep bowl (Schale) with } \\
\text { low-burnish surface and incised } \\
\text { decoration }\end{array}$ & $1 \mathrm{~A}$ & \\
\hline Sz 11/2 & $\begin{array}{l}\text { Undecorated, closed hole-mouth jar } \\
\text { (Kumpf) with smoothed surface }\end{array}$ & Loner & \\
\hline Sz 12 & $\begin{array}{l}\text { Undecorated, closed hole-mouth jar } \\
\text { (Kumpf) }\end{array}$ & $1 B$ & \\
\hline Sz 13/1 & $\begin{array}{l}\text { Thuringian cup with high-burnish } \\
\text { surface and pattern-burnish } \\
\text { decoration }\end{array}$ & Loner & \\
\hline Sz 13/2 & $\begin{array}{l}\text { Beutelförmig („Bag shaped”) stamped } \\
\text { jar/bowl? }\end{array}$ & Loner & \\
\hline Sz 15 & $\begin{array}{l}\text { Closed hole-mouth jar (Kumpf) with } \\
\text { impressed decoration }\end{array}$ & $1 B$ & \\
\hline Sz 16 & $\begin{array}{l}\text { Undecorated, closed hole-mouth jar } \\
\text { (Kumpf) with smoothed surface }\end{array}$ & $1 \mathrm{~A}$ & \\
\hline Sz 18 & $\begin{array}{l}\text { Biconical deep bowl (Schale) with low- } \\
\text { burnish surface and incised and } \\
\text { cuneate decoration }\end{array}$ & $1 \mathrm{~A}$ & \\
\hline
\end{tabular}


Table 1 (continued)
Undecorated, closed hole-mouth jar (Kumpf)

Sz 45
Sz 21

Sz 22

Sz 23

Sz 31

Sz 34

20

(21)

S
Grey burnished ware; single handled spouted bottle with pattern-burnish decoration

'S' profile deep bowl (Schale) with incised decoration and low-burnish surface

Undecorated, slightly biconical deep bowl/jar (Schale)

Undecorated, slightly biconical deep bowl (Schale)

Undecorated, closed hole-mouth jar (Kumpf) with smoothed surface

Undecorated biconical deep bowl (Schale)
$1 \mathrm{~B}$

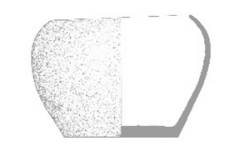

Loner

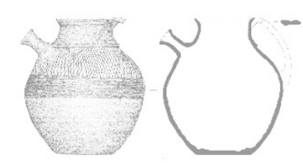

$1 \mathrm{~A}$

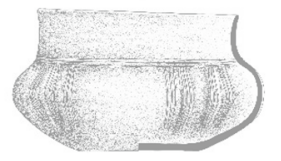

$1 C$

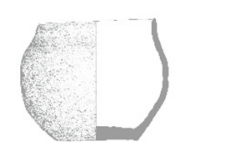

1B

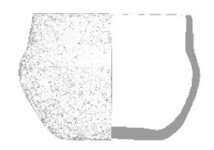

$1 \mathrm{~A}$

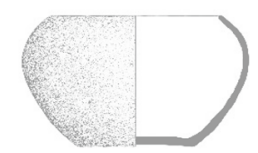

$1 \mathrm{~B}$

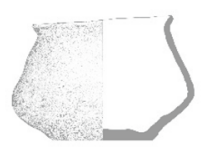

The pattern burnished, dark grey, single-handled, spouted bottle recovered from grave 21 ( $\mathrm{Sz} 21)$ can be associated with late Roman traditions. Grey-burnished wares (mainly rounded and biconical bowls, jugs, and jars) became widely used by the end of the fourth century in the whole Carpathian Basin and were popular during the fifth century (Ottományi, 1996, 2009, 2020). Despite that this decoration style is usually dated to the fifth century, this unique bottle shape with one handle and funnel-shaped spout is not known from fifth-century context so far. In fact, the closest parallels with regard to both its shape and decoration were recovered from the sixth-century cemeteries of Veszprém-Jutas (Rhé and Fettich, 1931), Kajdacs, and Szentendre (Bóna and Horváth 2009), along with a variant where instead of pattern burnishing, the surface was decorated with stamping (e.g. Zamárdi (Bocsi, 2008), Kápolnásnyék (Bóna and Horváth 2009)).

\section{Geological setting}

Szólád is located in the western part of Hungary-identical with the geographical region of Transdanubia-on the southern shore of Lake Balaton (Figs. 1-2). Looking at the southern lake shore from east to west, the geological environment displays slight changes that are compartmentalised by valleys of northwest to southeast direction. On the surface, most commonly Pleistocene loess can be observed, while on the steep hillsides in the upper parts of these valleys, the
Upper Pannonian (Miocene-Pliocene) Tihany Formation is exposed. The Tihany Formation is the basinal formation of the sedimentary sequence of the Pannonian lake, built up by finegrained siliciclastic rocks, mostly siltstones, marls, and finegrained sandstones and different types of clays (Gyalog 2005; Sztanó et al. 2013). Lower in the valleys, the PleistoceneHolocene slope debris gradually reveals itself, and then, at the bottom, alluvial deposits of Holocene age fill the valleys.

The northern lake shore-also known as the Balaton Highland-still within a $15 \mathrm{~km}$ radius of Szólád displays more diverse geological features. It is built up by various mostly sedimentary formations of Palaeozoic to recent age. The most characteristic formation of the Balaton Highland is the Permian red sandstone, which has fluvial origin and consists of predominantly felsic (dacitic) volcanic clasts. The terrestrial sedimentation then gradually changed to a lagoonal and shallow marine environment, where several types of marl, dolomite, and limestone formed in the Early and Middle Triassic. The Upper Triassic is characterized by thick (up to $3 \mathrm{~km}$ ) carbonate platform sediments, but these and younger (Jurassic and Cretaceous), predominantly deep marine, sediments are located in the inner parts of the Transdanubian syncline, further from the northern shore of Lake Balaton. The Neogene formations are subordinate in volume compared to the Palaeozoic and Mesozoic formations in the Balaton Highland. These are mainly a biogenic limestone (Tinnye Formation) and the 

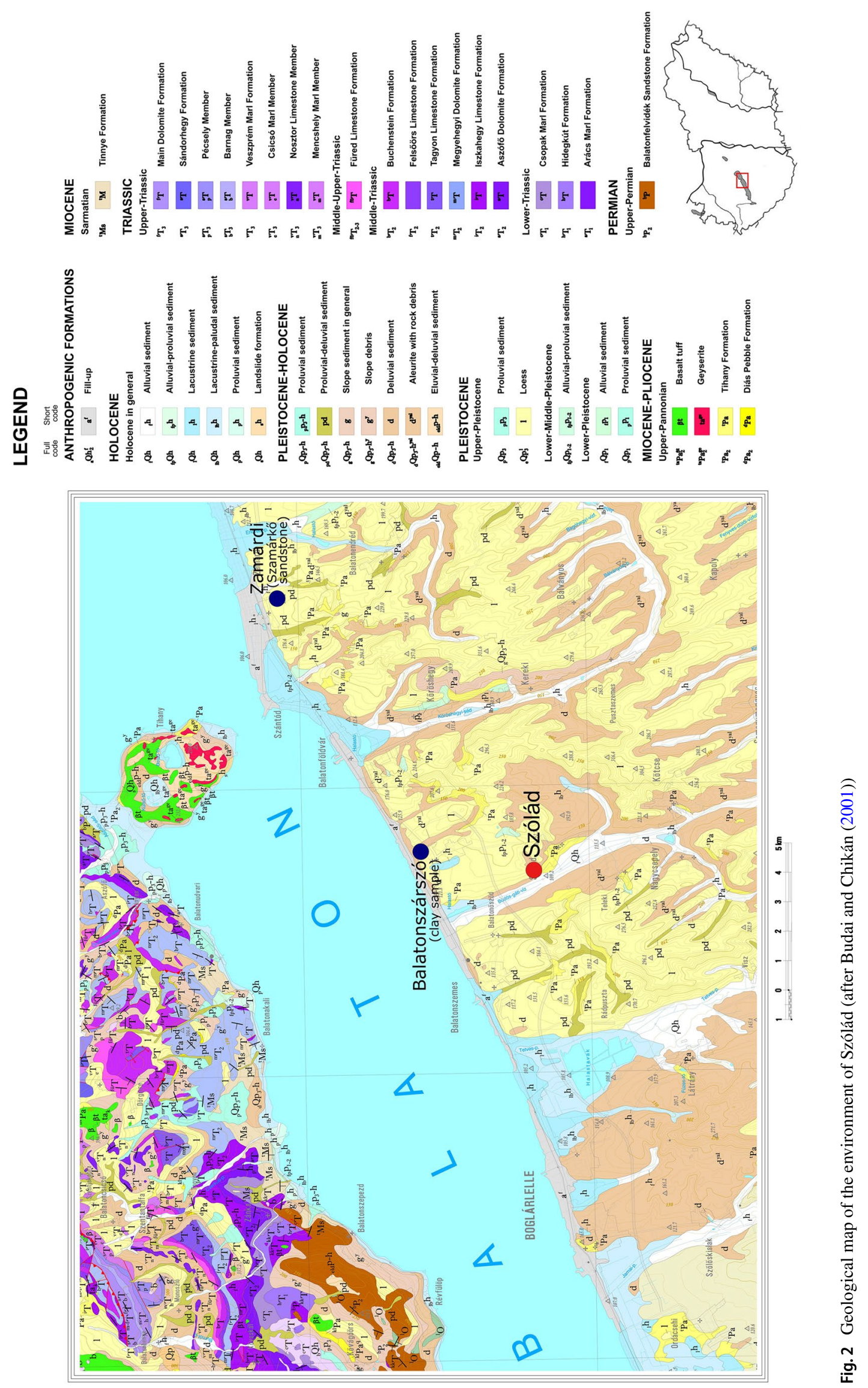
abovementioned Pannonian sediments (Tihany is in fact on a peninsula of the northern shore). Besides the occasional loess and Plio-Pleistocene alkali basalts, young terrestrial alluvialproluvial and deluvial deposits reworking the previously mentioned formations are present (Budai et al. 1999).

\section{Research objectives}

In recent years, significant effort has been made to develop new methods for understanding those social organisations and extensive migrations that shaped the centuries following the fall of the Western Roman Empire, in particular using isotopic and DNA analyses (e.g. Schuh and Makarewicz 2016; Vai et al. 2019; Csáky et al. 2020; Knipper et al. 2020). Such investigations in the case of the cemetery of Szólád were pioneering works in this field (Alt et al. 2014; Amorim et al. 2018). Despite this, only a limited number of more "conventional" scientific studies have been carried out on the archaeological finds from fifth- to sixth-century Pannonia. On pottery analysis, so far only preliminary petrographic studies have been published (Kern 2011, 2013; Pánczél-Bajnok et al. 2014).

The present study is the first combined petrographic and geochemical analysis performed on fifth- to sixth-century pottery from Pannonia. During this work, characterisation of the complete vessel assemblage was possible, as each pot from the cemetery was sampled for both optical microscopic and elemental analysis. The main aims were to identify the mineralogical and elemental composition of the pottery and subsequently attempt to reconstruct the different pottery fabric recipes and the technological choices made, to contribute to a better understanding of some aspects of the production sequence that can be observed by ceramic petrography, as part of the chaine opératoire approach (Roux 2019). Furthermore, it was our aim to examine the different raw materials used for their production and, if possible, to give an indication of the geological source of the raw material that have been utilized. Indicating the possible production areas is especially important as, so far, no pottery kilns or workshops from this period have been uncovered in Transdanubia. Such information regarding the composition and provenance of pottery not only aims to increase understandings of varied aspects of the production, trade, and consumption of pottery itself, but also to cast light on the cultural and technological dynamics of the mobile communities living in post-Roman Pannonia.

\section{Methodology}

\section{Polarised light optical microscopy (OM)}

Nineteen complete ceramic vessels and one potsherd have been found in the cemetery of Szólád, of which each one was sampled and subsequently prepared as uncovered petrographic thin sections. The thin sections were analysed using a Zeiss AxioScope A1 equipped with a Zeiss AxioCam MRc5 digital camera, and a Nikon Eclipse LV100N polarising light microscope with a Nikon DS-Fi3 microscope camera; the photomicrographs were processed using Zeiss AxioVision 4.9.1 and NIS Elements BR software. The magnification during the examination was between $\times 20$ and $\times 1000$. The analysis was carried out at the Archaeometry Laboratory of the Institute of Archaeological Sciences, Eötvös Loránd University, Budapest, and at the Neutron Spectroscopy Department of the Centre for Energy Research. In the petrographic descriptions, we considered the guidelines of Whitbread (1995), Quinn (2013), and Montana (2020).

In addition to the twenty samples from Szólád, we had access to five thin sections from the collections of two Hungarian museums, which have been used as reference samples in this study. Approximately $5 \mathrm{~km}$ to the north of Szólád, coarse-grained and fine-grained local clay sediments have been collected from the site of the middle Neolithic settlement of Balatonszárszó (Kreiter and Pánczél, 2013; Kreiter et al. 2017, marked in Fig. 2). Now part of the collection of the Laboratory of Applied Research of the Hungarian National Museum, we were able to examine two thin sections sampled from these local Balatonszárszó sediments. The microscopic examination was carried out, and the photomicrographs used in this article were taken at the Laboratory of Applied Research. Furthermore, from the collection of the Kuny Domonkos Múzeum, Tata, we examined three thin sections that were sampled from a carbonate-cemented sandstone outcrop, the Szamárkő at Zamárdi (marked in Fig. 2), ca. 12 km northeast of Szólád. These thin sections were examined, and photomicrographs were taken at the Kuny Domonkos Múzeum.

\section{Scanning electron microscopy (SEM-EDS)}

Following the initial petrographic analysis, one sample (Sz 13/1) was selected for further analysis by scanning electron microscopy coupled with energy dispersive spectroscopy (SEM-EDS). This sample differed significantly from the others with regard to both the petrographic and bulk chemistry results. The optical microscopic examination revealed that this sample contains such inclusions that might bear importance in narrowing down the geological origin of the vessel; therefore, our aim was to measure the compositions of these inclusions locally.

The SEM-EDS analysis was carried out at the Electron Microscope Laboratory of the Department of Petrology and Geochemistry, Eötvös Loránd University, Budapest, using an AMRAY 1830 scanning electron microscope equipped with an EDAX PV9800 energy dispersive spectrometer. The surface of the sample was coated with carbon, and the 
analysis was performed in a vacuum $\left(10^{-3} \mathrm{~Pa}\right)$. During the analysis, the conditions were $20 \mathrm{kV}$ accelerating potential, 1 $\mathrm{nA}$ beam current, $\sim 50-100 \mathrm{~nm}$ focused electron beam diameter, and 100-s measurement time of each analysis. Natural silicate and oxide standards and ZAF correction were used to evaluate the EDS spectra. Typically, one point per inclusion was measured, whereas for matrix measurements, areas that appeared homogenous in the backscattered electron images were set manually to ca. $50-100 \mu \mathrm{m}^{2}$.

\section{Elemental analysis (PGAA, NAA)}

Neutron-based methods were applied to characterise the bulk elemental composition of each pot from Szólád, providing concentrations for 12 major elements and 24 minor and trace elements. The concentrations of major elements, together with some minor and trace elements, were measured by prompt gamma activation analysis $(\mathrm{Si}, \mathrm{Ti}, \mathrm{Al}, \mathrm{Fe}$, $\mathrm{Mn}, \mathrm{Ca}, \mathrm{Na}, \mathrm{K}, \mathrm{Mg}, \mathrm{C}, \mathrm{H}, \mathrm{P}, \mathrm{B}, \mathrm{Cl}, \mathrm{V}, \mathrm{Gd}$ ), while additional minor and trace elements were obtained by neutron activation analysis $(\mathrm{Br}, \mathrm{Rb}, \mathrm{Th}, \mathrm{U}, \mathrm{Zr}, \mathrm{Hf}, \mathrm{Ta}, \mathrm{Y}, \mathrm{La}, \mathrm{Ce}, \mathrm{Nd}, \mathrm{Sm}$, $\mathrm{Eu}, \mathrm{Gd}, \mathrm{Tb}, \mathrm{Yb}, \mathrm{Sc}, \mathrm{V}, \mathrm{Cr}, \mathrm{Co}, \mathrm{Zn}, \mathrm{Cs}, \mathrm{Ga}, \mathrm{As})$. In those cases where the elements could be analysed with both methods ( $\mathrm{Ca}, \mathrm{Co}, \mathrm{Cr}, \mathrm{Fe}, \mathrm{Gd}, \mathrm{K}, \mathrm{Nd}, \mathrm{Sc}, \mathrm{Sm})$, the results of the more sensitive or reliable method are given, based on previous studies (Szilágyi et al. 2012; Gméling et al. 2014). Ca, $\mathrm{K}, \mathrm{Fe}, \mathrm{Na}, \mathrm{K}$, and $\mathrm{Gd}$ were obtained from PGAA data, while for $\mathrm{Co}, \mathrm{Cr}, \mathrm{Nd}, \mathrm{Sc}$, and $\mathrm{Sm}$ concentrations, NAA results were used. With the combination of the two complementary methods, the concentration or detection limits of (almost) every component of unknown samples can be determined.

In case of the NAA, the samples were precisely weighed $(0.13-0.56 \mathrm{~g})$ and wrapped in high-purity aluminium foil and then were irradiated for $12 \mathrm{~h}$ at the Budapest Research Reactor (Szentmiklósi et al. 2016). Each sample was measured twice; the first decay-gamma measurements were done after 78-135 h of cooling time with 15-20 min of counting time. The second sets of measurements were performed after 26-34 days of cooling time and were counted for 150-180 min. The gamma-spectra were evaluated with HyperLab 2013.1 software (Simonits et al. 2003), while for the element identification, concentration, and detection limit calculation, KayZero for Windows 3.06 was used (De Corte et al. 2001). The software is based on the database provided by the $k_{0}$ International Scientific Committee ("www.kayze ro.com" 2021).

In this study, the samples taken originally for the optical microscopy were analysed with both PGAA and NAA, weighing $0.6-0.8 \mathrm{~g}$ each. For PGAA, the samples were sealed into polytetrafluoroethylene (PTFE) bags and then were placed into an aluminium sample frame between PTFE strings. No further sample preparation was needed. The typical penetration depth in case of matrices dominantly consisting lighter elements is circa $30 \mathrm{~mm}$ (Szentmiklósi et al. 2021), which means that this non-destructive method is highly representative even in case of large objects. The emitted gamma rays were detected with Compton-suppressed high purity germanium (HPGe) detector. The spectrum evaluation was performed using Hypermet-PC and GammaFit software (Révay et al. 2005; Szentmiklósi 2018). The calculation of uncertainties, the process of the element identifications, and the concentration calculations were undertaken as per earlier studies (Révay 2006, 2009). Both PGAA and NAA facilities are operated by the Nuclear Analysis and Radiography Department of the Centre for Energy Research.

\section{Statistical evaluation}

A statistical approach was used to evaluate the results of the prompt gamma and neutron activation analyses, following the guidelines of Papageorgiou (2020). Owing to the small number of analysed samples $(n=20)$, major elements and minor/trace elements were evaluated separately. In each case, the dataset was normalised (from all the values, the mean was subtracted and then divided by the standard deviation). Some elements were excluded from the analysis: in the cases of $\mathrm{CO}_{2}$ (probably in form of $\mathrm{CaCO}_{3}$ or $\mathrm{MgCa}\left(\mathrm{CO}_{3}\right)_{2}$ in the samples) and $\mathrm{U}$, the dataset was incomplete due to their low concentration or high detection limit, while $\mathrm{H}_{2} \mathrm{O}, \mathrm{P}_{2} \mathrm{O}_{5}$, As, and $\mathrm{Ga}$ are not conventionally used in geochemical evaluation, as they might be connected to secondary depositional processes. Principal component analysis (PCA) was carried out on the datasets. The PCA scores, contribution values, and $\cos ^{2}$ values of the variables can explain the correlations between each element, their role in the formation of PCA axes, and the spread of the individuals of the sample.

For the validation of the fabric groups previously determined by optical microscopic examination, $k$-means clustering was also carried out on the PCA scores of the individuals of the sample. The number of $\mathrm{k}$ groups used in the analysis was determined by Cattell's scree test. The $k$-means clustering method classified the PCA scores into k-groups on the basis of their intra-class similarities and their group's inter-class similarities, which was defined by their means (centroid). The combination of these methods above could clearly reflect on the possible grouping diversity of the samples.

\section{Results}

\section{Petrographic investigations}

From the petrographic analysis, one main fabric group (FG 1) has been distinguished, incorporating $80 \%$ of the entire assemblage (16 samples), while four samples were defined as loners. Fabric group 1 is characterised by fine to coarse sand-sized inclusions in non-calcareous, silty, micaceous 
clay. The sand-sized inclusions can be associated with the locally available Upper Pannonian sediments and sandstone of the Tihany Formation (Fig. 2). Based on the size, sorting, and amount of this sand, three subgroups have been defined, which are described separately.

\section{FG $1 A$}

Sz 1, Sz 3, Sz 10/1, Sz 11/1, Sz 16, Sz 18, Sz 22, Sz 34 Eight samples belong to FG 1A (Table 1, Fig. 3a-h). These samples are characterised by a slightly heterogeneous, silty micromass with high optical activity, light brown in plane polarised light (PPL), and light to medium brown and reddish brown with crossed polars (XP). Meso- and macrochannels are occasionally visible in thin sections. These samples have weak hiatal fabrics (the size range of the inclusions is not entirely continuous from the smallest to the largest), and the aplastic inclusions are moderately/ poorly sorted and display weakly bimodal grain-size frequency distribution. The silt-sized inclusions $(<63 \mu \mathrm{m})$ in the non-calcareous clay are rare to very few $(0.5-5 \%)$; they are characterised by muscovite, monocrystalline quartz, and feldspars. The coarse fraction consists of inclusions between ca. 100 and $1000 \mu \mathrm{m}$, and the dominant grain size is medium sand $(250-500 \mu \mathrm{m})$. Altogether they form about $25 \%$ of the field of view.

In the coarse fraction, we find mineral clasts and rock fragments as well. The most common inclusions are monocrystalline quartz (of both volcanic and metamorphic origin), saussuritic and sericitic plagioclase with polysynthetic twins (mainly oligoclase), perthitic K-feldspar (mainly orthoclase and microcline), polycrystalline quartz, monocrystalline sparry calcite, chert, clastic origin muscovite and biotite, microsparry dolomite with equigranular, idiotopic-hypidiotopic fabric or slightly decomposed groundmass, carbonate concretions, and lithic sandstone fragments as the combination of these inclusions cemented by carbonate. The carbonate cement is either in a form of coarse-grained calcite crystals forming a poikilotopic fabric (e.g. shown in Fig. 3e) or forms a micritic carbonate matrix, where secondary calcitisation is often visible. A few other rock fragments are also present in the samples, such as fragments of quartzite, arenaceous sandstone sometimes with Fe-rich cement, marl, biotite and muscovite schist, siltstone/ meta-siltstone/mudstone, chloritic quartzite, Mesozoic fossiliferous limestone, gneiss-granitoid rocks, and graphite phyllite. In some cases, traces of carbonate cement can be observed around these rock fragments as well, which suggests that these fragments were also derived from the carbonate-cemented sandstone that can be observed broken up in these samples. The siliciclastic inclusions appear to be fresh, being angular to subangular, while chert, dolomite, limestone marl, and the carbonate concretions are usually very well rounded. The carbonate-bearing inclusions vary in appearance, with sharp to merging boundaries, which might be explained by the thermal processes during firing. Samples in FG 1A are rich in accessory minerals, among them epidote, zoisite, staurolite, tourmaline, garnet, chloritoid, and amphibole can be found. Occasional limonitic clay concretions, clay pellets, mollusc shells, radiolarite, and opal siliceous sponge needles also occur in the samples. Selected photomicrographs representing typical inclusions of FG $1 \mathrm{~A}$ can be found in Figure S2a, c, e, and g and in Figure S2a, c, $\mathrm{e}$, and $\mathrm{g}$ in the Supplementary Materials.

\section{FG 1B}

Sz 2, Sz 10/2, Sz 12, Sz 15, Sz 20, Sz 31, Sz 45 This fabric group contains seven samples (Table 1, Fig. 4a-g). These samples are characterised by a homogenous, silty micromass that shows weak or no optical activity; they display dark grey to dark brown colour in PPL and dark reddish brown to dark greyish brown colour in XP. Meso- and macro-channels and occasional vughs can be detected in the fabric. These samples have hiatal fabrics (the size range of the inclusions is not continuous from the smallest to the largest), and the aplastic inclusions are very poorly sorted and display strong bimodality. The fine fraction ranges from silt size $(\sim 20 \mu \mathrm{m})$ to fine sand size $(\sim 200 \mu \mathrm{m})$ and occupy ca. $20 \%$ of the field of view. The dominant grain size of this fraction is very fine to fine sand $(100-150 \mu \mathrm{m})$. The coarse fraction consists of aplastic inclusions between ca. 600 and $1300 \mu \mathrm{m}$, dominantly ca. $1000 \mu \mathrm{m}$. Despite the differences in their size, the mineral assemblage in the coarse-grained fraction is also present in the fine fraction, while some inclusions only appear in the fine fraction. Together the two fractions form approximately $30-35 \%$ of the field of view.

The suite of inclusions observed in this fabric groupboth main components and accessory minerals - agrees with those identified in FG 1A; similarly, they contain fragments of rocks and minerals derived from carbonate-cemented sandstone; however, the well-rounded coarse-grained inclusions suggest that they are from a different fraction of the same sediment. The main difference between the two subgroups is that the grain-size frequency distribution of FG $1 \mathrm{~B}$ appears to be strongly bimodal, where the fine fraction is more fine-grained and abundant, while a distinctive fraction can be observed, characterised by very coarse, very wellrounded dolomite with relic microsparry texture or slightly decomposed groundmass, chert, carbonate concretions, radiolaritic chert, mollusc shells, limestone, and fossiliferous limestone fragments. In one case (Sz 15, Fig. 4d), very coarse, well-rounded sparry calcite and orthoclase were also identified in this fraction. Another distinctive aspect in FG $1 \mathrm{~B}$ is that the relative ratio of calcite-cemented sandstone 


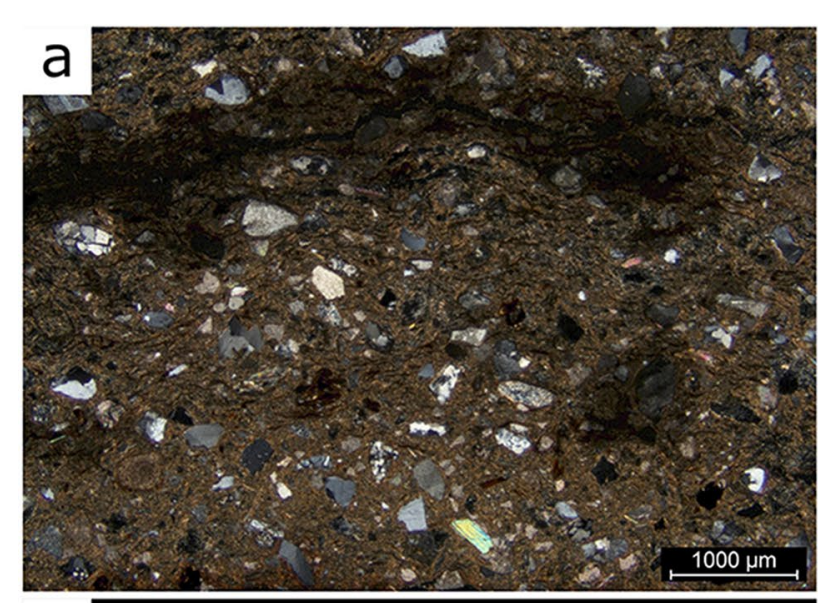

b
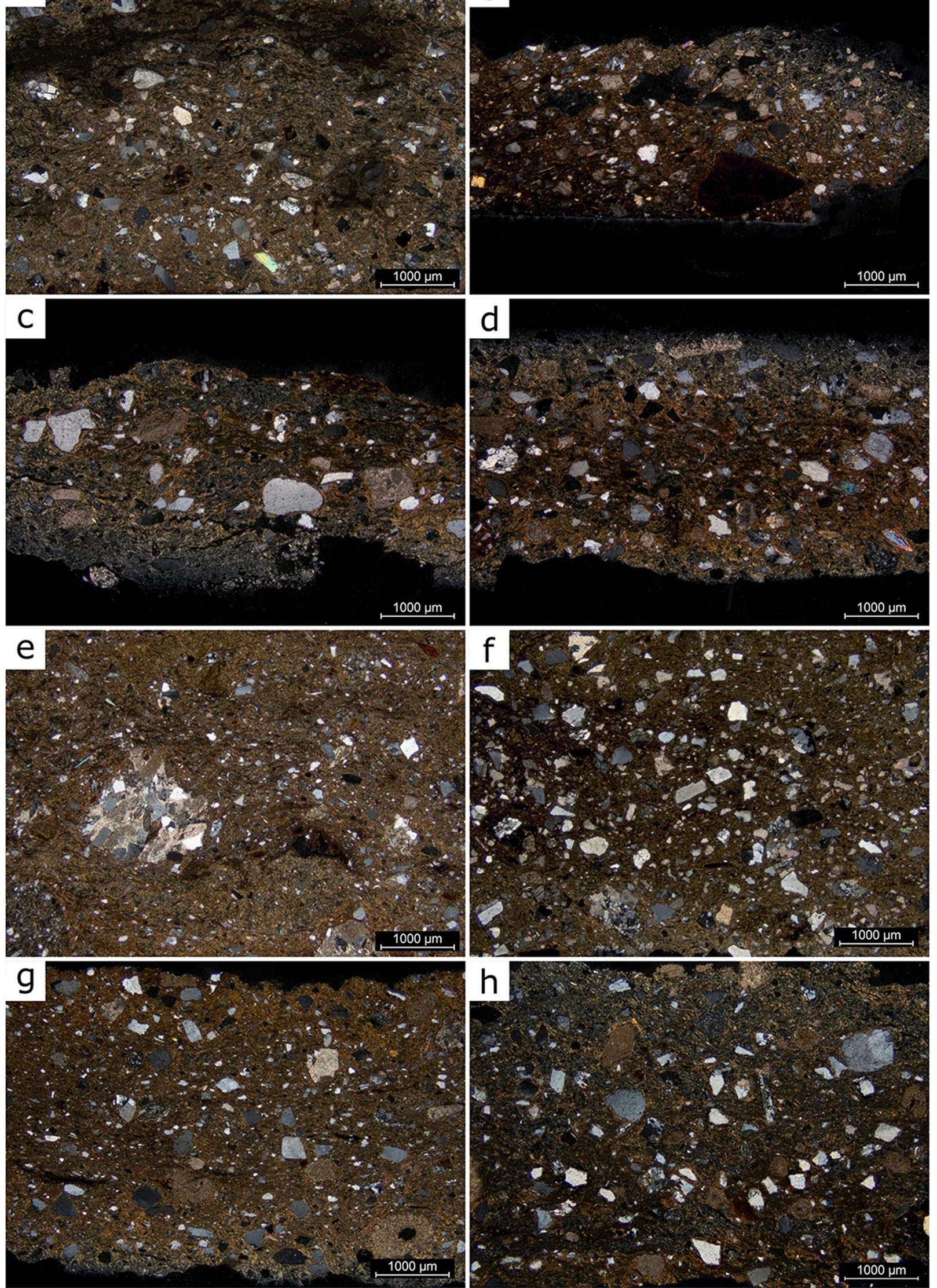

$\mathrm{h}$

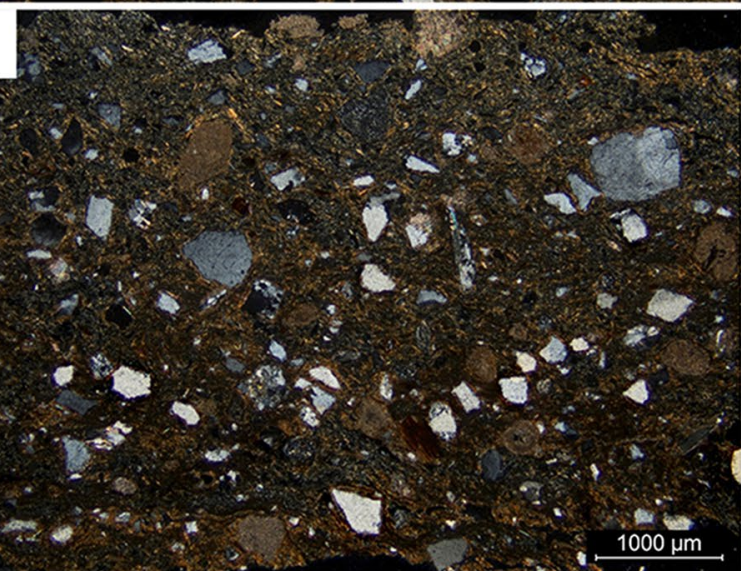


4Fig. 3 Photomicrographs of samples belonging to fabric group 1A. All images were taken with XP, magnification $=\times 20$. a Sz $1, \mathbf{b ~ S z} 3$, c Sz 10/1, d Sz 11/1, e Sz 16, f Sz 18, g Sz 22, and h Sz 34

fragments, although present, is less than that in FG 1A. This, and the generally better-rounded aplastic inclusions present in this subgroup, suggests that this sand came from a more mature part of the same geological formation as FG $1 \mathrm{~A}$. Selected photomicrographs representing typical inclusions of FG $1 \mathrm{~B}$ can be found in Figure S1b, d, f, and h and in Figure $\mathrm{S} 2 \mathrm{~b}, \mathrm{~d}, \mathrm{f}$, and $\mathrm{h}$ in the Supplementary Materials.

\section{FG 1C}

Sz 23 One sample was distinguished from the above subgroups as FG $1 \mathrm{C}$, as it represents a transition between FG $1 \mathrm{~A}$ and $1 \mathrm{~B}$, while characterised by similar raw materials (Table 1, Fig. 4h). The silty micromass of this sample appears to be homogenous and is optically active, and it displays medium brown colour in PPL and dark reddish brown in XP. The groundmass is richer in coarse silt-sized muscovite compared to FG 1A and 1B. Meso- and macrochannels are visible in thin section. This sample has hiatal fabric, with poorly sorted aplastic inclusions displaying a bimodal grain-size frequency distribution. The fine fraction is characterised by angular, coarse silt to very fine sand inclusions, occupying ca. $35 \%$ of the field of view. Compared to FG $1 \mathrm{~A}$ and $1 \mathrm{~B}$, the dominant grain size of this fraction appears to be finer, and their relative ratio is higher; however, the same carbonate-cemented sandstone fragments and its individual mineral inclusions can be identified in this sample as in the previous subgroups. The coarse-grained fraction is characterised solely by coarse sand-sized (500-1000 $\mu \mathrm{m})$, well-rounded, altered carbonate concretions (probably of dolomitic/limestone origin) with diffuse boundaries, and carbonate "ghosts" (Fig. 4h, left), that altered or exited the ceramic body due to higher maximum temperature/longer soaking period during firing. In this sample, chert and other siliciclastic inclusions in the coarse fraction are missing.

\section{Loners}

Four samples significantly differed from the main petrographic fabric group as well as from each other; therefore, they were defined as loners, and they are described below separately (Table 1, Fig. 5a-h).

Sample Sz 11/2 (Fig. 5a-b) was readily distinguished under the microscope by the very coarse sand-sized inclusions of sparry calcite and dolomite. In thin section, this sample displays a homogenous, optically active micromass, dark brown in PPL and dark reddish brown in XP, with common large, parallel, elongate voids. The fabric is hiatal, and the inclusions are very poorly sorted and display strong bimodal frequency distribution; together they form ca. $40 \%$ of the field of view. The fine fraction consists of moderately sorted, open spaced, angular to subangular inclusions between 10 and $80 \mu \mathrm{m}$, primarily muscovite, commonly monocrystalline quartz, feldspars, and rare calcite, together occupying ca. 2-5\% of the field of view. The coarse fraction is dominated by two types of inclusions: angular, coarse to very coarse sparry calcite fragments of ca. $0.7-2.5 \mathrm{~mm}$ and very well-rounded dolomite inclusions of ca. $0.5-1 \mathrm{~mm}$. The shape of the sparry calcite grains is usually formed by the rhombohedral cleavage planes, characteristic twin lamellae are often visible (types II and IV, according to Burkhard (1993)), and occasionally, within the calcite grains, accessory minerals (pyroxene (diopside), monocrystalline quartz, and apatite) (Fig. 5a) are present. These characteristics suggest that the sparry calcite fragments observed in this sample originate from marble, and not from vein calcite, speleothems, or crystalline limestone. The dolomite inclusions typically have equigranular microsparry texture $(20-40 \mu \mathrm{m})$ with characteristic euhedral crystals, or, less frequently, very fine-grained plastic groundmass. Apart from the marble and dolomite inclusions, occasionally coarse-grained monocrystalline quartz, sandstone/metasandstone, siltstone, mollusc shell, and the same type of calcite-cemented sandstone fragment as observed in FG1 are also present in the fabric (Fig. 5b). The vastly different angularity of the marble and dolomite inclusions suggests that they might have a different origin; the rounded shape of the dolomite inclusions suggests that they are derived from a sand-sized sediment formed in strongly eroded, water-rich environment, whereas the angular marble fragments may have been intentionally crushed before adding as a temper to the clay paste. As such, therefore, these two components of the coarse fraction need not necessarily originate from the same geological area. In fact, apart from the marble fragments, the suite of inclusions present in this sample corresponds with those described in FG 1 .

Sample Sz 13/1 (Fig. 5c-d) represents a very fine-textured, non-calcareous ceramic paste without deliberate additional temper that is distinguished by significant amount of mafic inclusions observed in its fabric. This sample has an optically active, heterogeneous micromass with rare mesochannel voids. Both in PPL and with XP, a sharp border can be observed between the light brown and greyish brown parts that divides the sample in half, which can be linked to a change of atmosphere during firing. Under higher magnification, a few inhomogeneities and Fe-rich pellets in the clay are occasionally visible. The fabric of this sample is serial, displaying a unimodal grain-size frequency distribution with angular, moderately sorted inclusions between 10 and $150 \mu \mathrm{m}$ that occupy ca. $15-18 \%$ of the field of view. The 

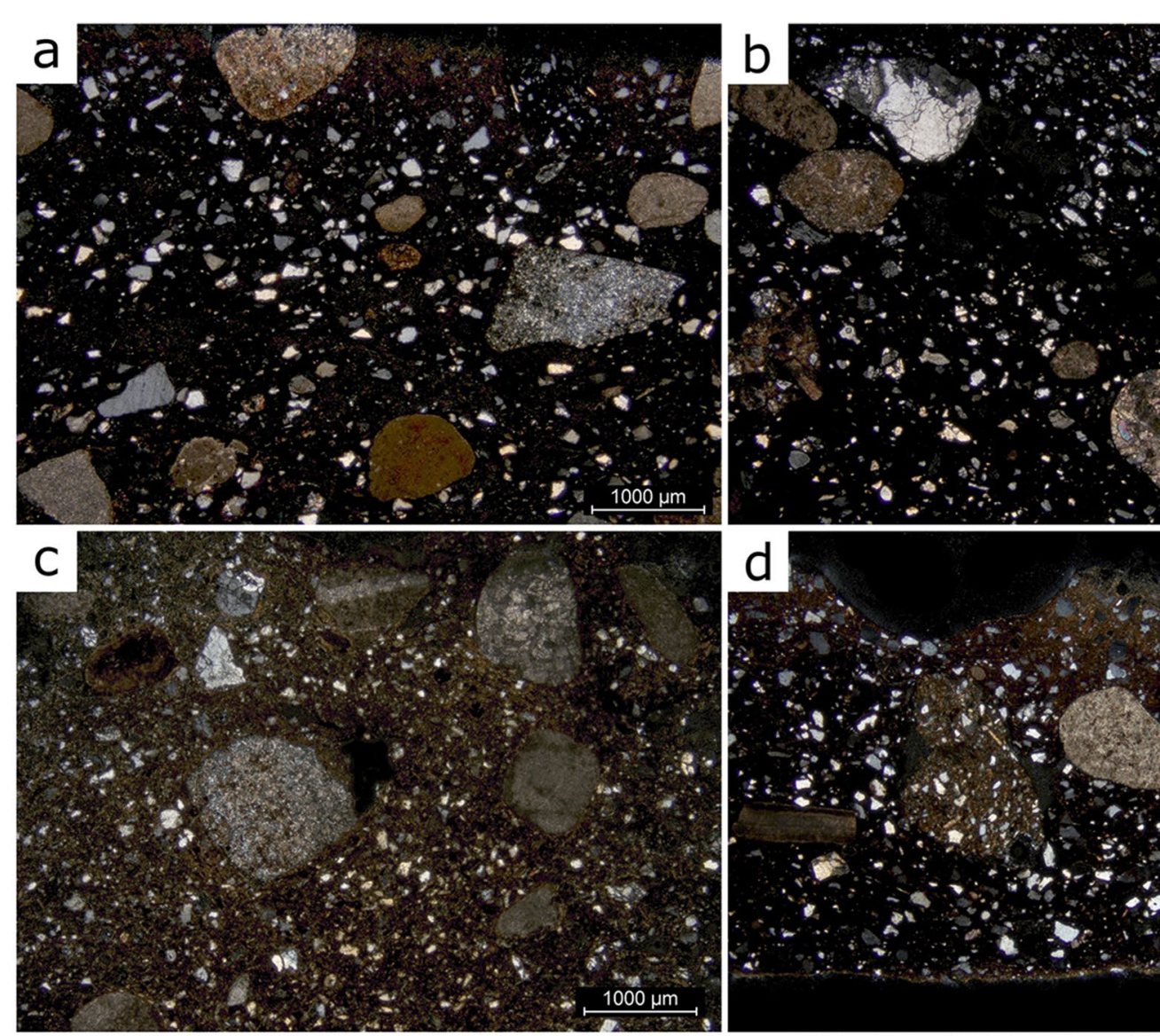

d

d

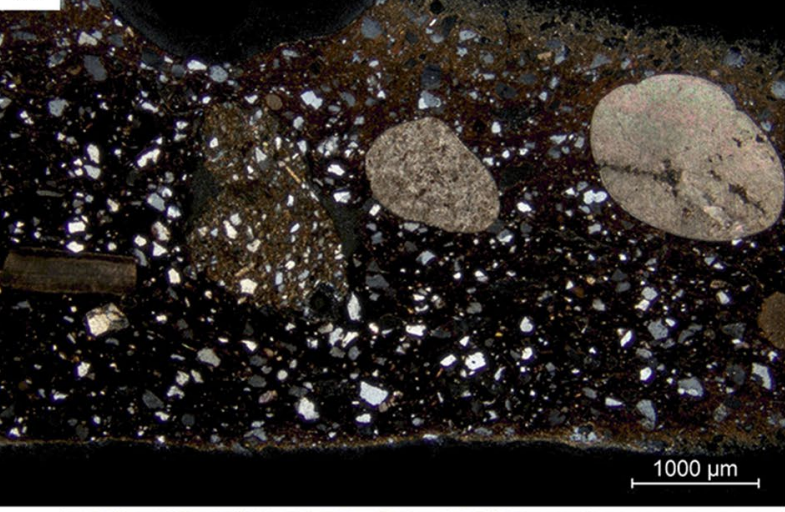

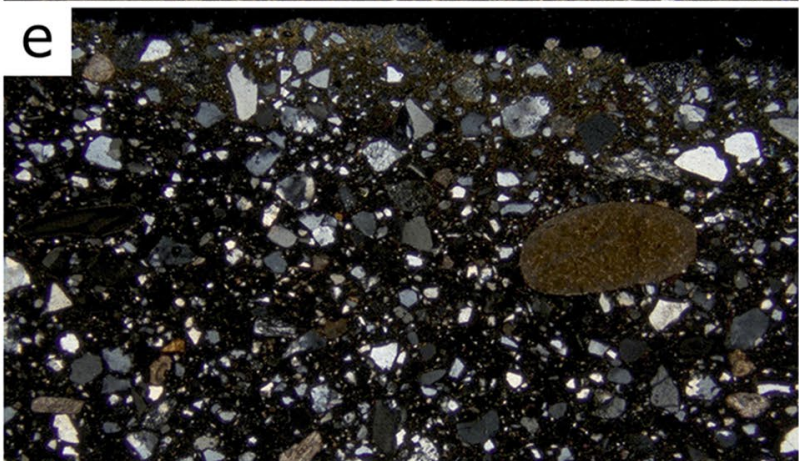

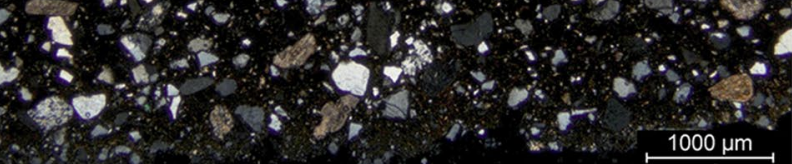

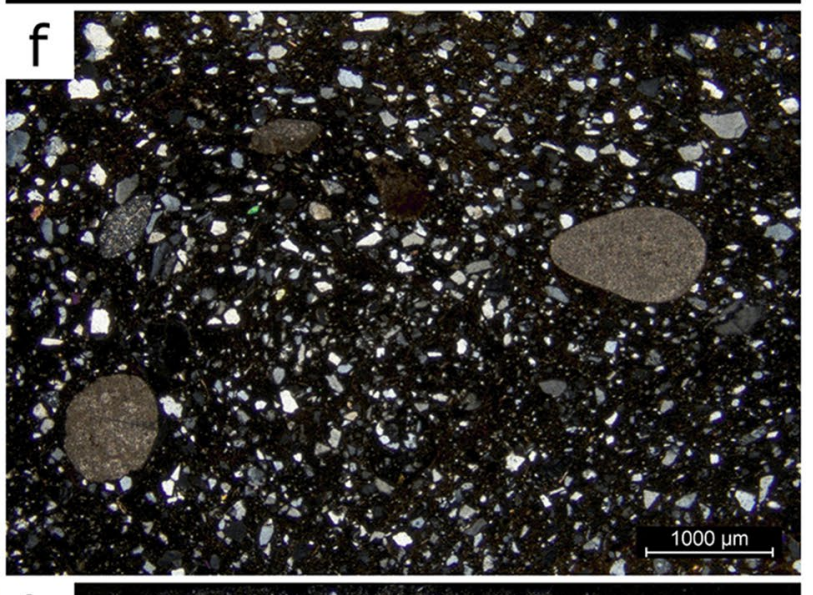

\section{g}

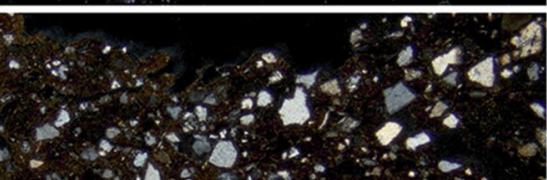

h
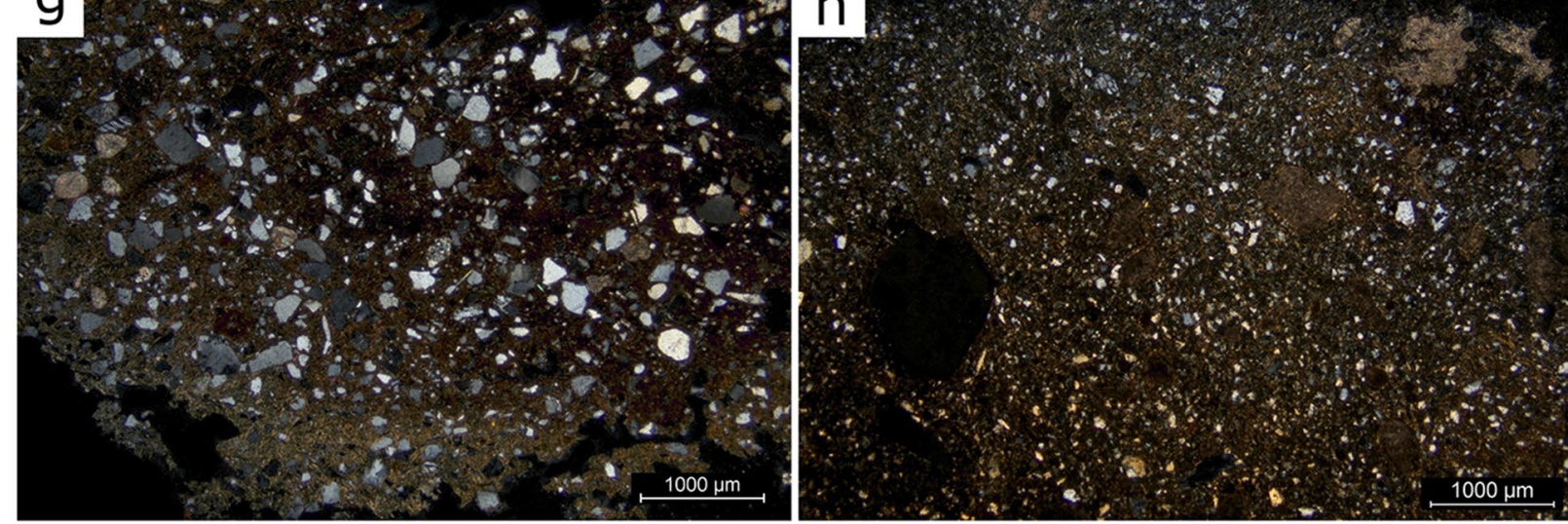
4Fig. 4 Photomicrographs of samples belonging to fabric group 1B (a-g) and 1C (h). All images were taken with XP, magnification $=\times 25$. a Sz 2, b Sz 10/2, c 12, d 15, e Sz 20, f Sz 31, g Sz 45, and $\mathbf{h} \mathrm{Sz} 23$

inclusions are dominantly muscovite, quartz, plagioclase, K-feldspar, commonly biotite (often altered into chlorite), amphibole, pyroxene, and opaque minerals. Few apatite, epidote, and garnet are also present. Furthermore, the sample also displayed common inclusions of glass phases, typically seen as spherules, but occasionally as fragments with conchoidal fractures, ca. $10-50 \mu \mathrm{m}$ in size, the composition and origin of which could not be determined by OM. In order to better understand the origin and connection of both the glass and other mineral inclusions, this sample was further analysed by SEM-EDS (see the "SEM-EDS" section).

Sample Sz 13/2 (Fig. 5e-f) is characterised by poorly sorted, medium-grained fabric rich in argillaceous inclusions that can be interpreted as grog temper. It has an optically active, heterogeneous micromass that displays light brown to medium brown colour in PPL, and medium brown to dark brown colour with XP. In the fabric, a few meso- and macro-voids are identified. The poorly sorted, serial fabric contains subangular to rounded, coarse silt to medium sandsized siliciclastic inclusions that occupy ca. $25 \%$ of the field of view: dominantly muscovite and monocrystalline quartz, commonly polycrystalline quartz, K-feldspar, plagioclase, and opaque minerals. The variety in roundness within the different species of siliciclastic inclusions suggests that the clay utilized was a polymictic sediment comprising minerals of different origin. Traces of decomposed or partially decomposed carbonate can be observed. Common-few argillaceous inclusions of various sizes $(100-500 \mu \mathrm{m})$ approximately evenly distributed are present in the fabric. These inclusions are angular to subrounded, typically prolate with sharp boundaries, and their colour varies from dark reddish brown to light brown, at times almost identical with the colour of the groundmass. They typically contain slightly fewer siliciclastic inclusions with a composition similar to the rest of the sample. In one case, a "second-generation" inclusion incorporating an older inclusion can be observed (Fig. 5f). This information is indicative of the deliberate use of grog temper (Whitbread 1986).

Sample Sz 21 (Fig. 5g-h) is distinguished by its very well-sorted, very fine-grained, non-calcareous fabric lacking any deliberately added temper. It has a homogeneous, optically active micromass that displays a medium greyish brown colour in PPL, and medium brown in XP. Meso-sized channel voids are occasionally detected in the fabric, along with rare organic residues. The serial, very well-sorted, clay-rich fabric is characterised by a unimodal grain-size frequency distribution. The aplastic inclusions occupy ca. $15 \%$ of the field of view. The dominant grain size is between
20 and $30 \mu \mathrm{m}$. Among the aplastic inclusions, monocrystalline quartz and muscovite are dominant, and polycrystalline quartz, plagioclase, and K-feldspar are common. Apart from muscovite (and occasional biotite) that usually appears as elongated single flakes in the thin section, the other minerals in the fabric are angular and equant. This sample is relatively rich in accessory minerals with epidote, zoisite, biotite, amphibole (tremolite) and garnet identified.

\section{SEM-EDS}

Sz 13/1 (Thuringian cup) was further analysed with SEM-EDS in order to gain chemical information locally about selected inclusions and the clayey matrix. The main aim of this analysis was to better understand the composition of the inclusions and clay-rich matrix as a whole and thus to determine the geological environment from which the raw materials used to produce the vessel were obtained. The elemental compositions of amphiboles, plagioclases, pyroxenes, and garnets were measured quantitatively, along with the clay matrix and the glass spherules formerly observed by polarising microscope. All the measurement data are available in the Supplementary Materials (Table S4-S9).

The amphiboles fall into two main compositional groups: those associated with low-grade metamorphism (Al-rich actinolitic amphiboles), and $\mathrm{Na}-\mathrm{Ca}$-amphiboles suggesting medium-grade metamorphic/igneous origins (Fig. 6). Among the measured plagioclases, sodic (albite) and intermediate (andesine-oligoclase) ones were measured (Fig. 7); however, pure albite (with no detectable $\mathrm{Ca}$ or $\mathrm{K}$ ) and pure K-feldspar (with no detectable Na) were identified as well in the sample in significant amounts. Compared to the quantity of amphiboles in the sample, fewer pyroxenes were observed; the two analysed grains were classified as augite and diopside, respectively, indicative of originating from different rock types. Most garnets measured in the sample contained ca. 50\% almandine; however, one inclusion was richer in $\mathrm{Mn}$ and poorer in Ca. Additionally, apatite (frequent), epidote, $\mathrm{TiO}_{2}$, hematite (moderate), monazite, zircon, and xenotime (few) were also identified in this sample.

Based on the above information, it can be concluded that the clay sediment used for this vessel contained the debris of several rock types of different origin. The actinolitic amphiboles and sodic albites are indicative of greenschist facies origin. In addition, some small $(<40 \mu \mathrm{m})$ rock fragments consisting of quartz and actinolite, together with relatively common epidote, are also consistent with the greenschist source, and, although chlorites are probably pseudomorphs after biotite, they may also originate from greenschist facies rocks. On the other hand, $\mathrm{Ca}-$ and $\mathrm{Na}-\mathrm{Ca}$-amphiboles (ferropargasite, pargasite, magnesiohornblende) and intermediate plagioclases suggest the presence of amphibolites (where garnets can also be present in their higher pressure 

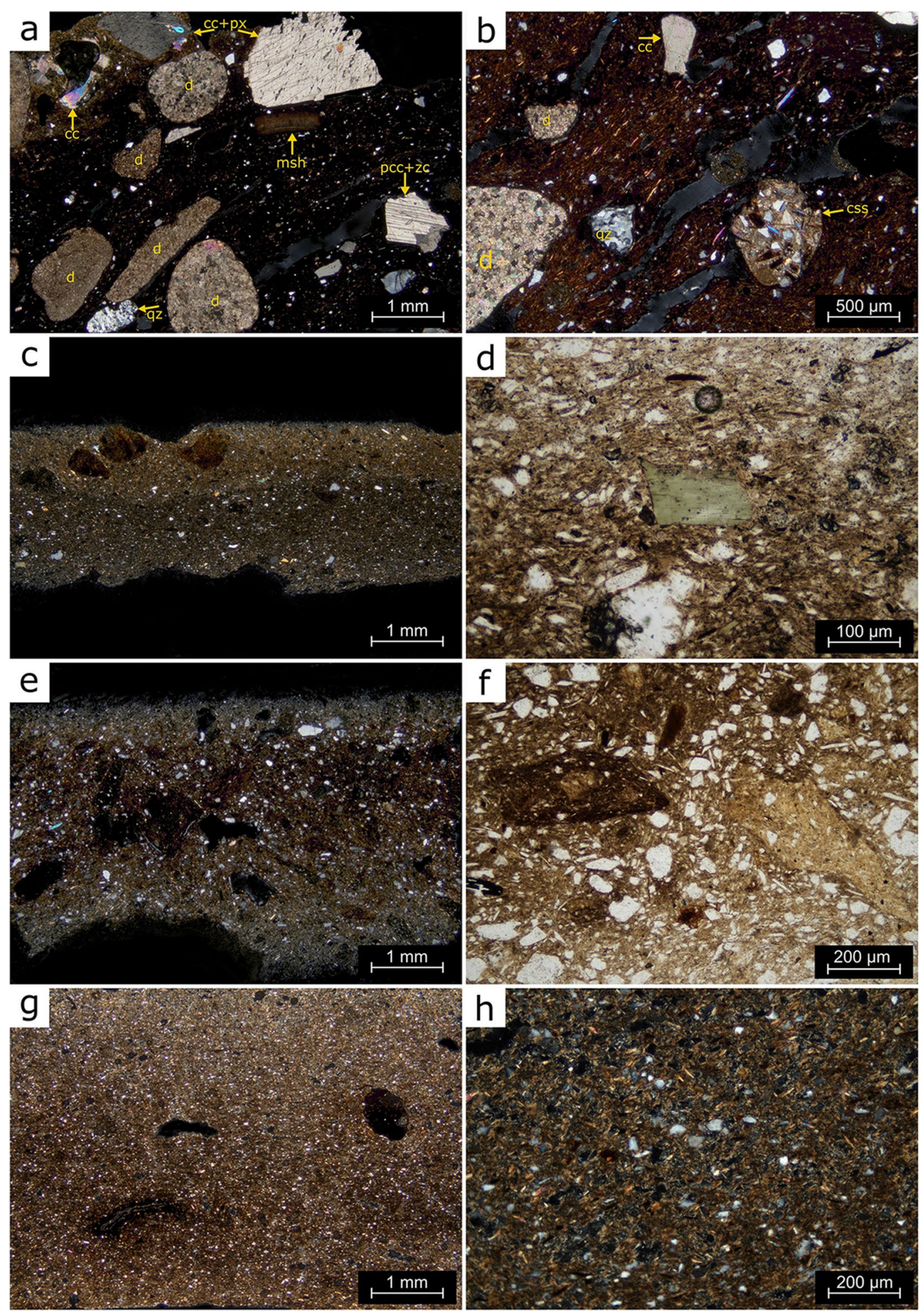

Fig. 5 Photomicrographs of the loners. a-b Sz 11/2 (loner 1, marble and dolomite temper). a Angular monocrystalline ( $c c)$ and polycrystalline ( $p c c)$ calcite fragments identified as marble, together with pyroxene $(p x)$ and zircon $(z r)$ accessories, rounded dolomite $(d)$ and quartzite $(q z)$ fragments, and a mollusc shell $(m s h)$ displayed in the fabric of $\mathrm{Sz} 11 / 2(\mathrm{XP}, \times 20)$. b Well-rounded carbonate-cemented sandstone fragment (css) consistent with the neighbouring Szamárkő sandstone and well-rounded dolomite and quartzite in the fabric of Sz 11/2 (XP, ×40). c-d Sz 13/1 (loner 2, Thuringian cup). c The fabric of $\mathrm{Sz} 13 / 1$ in $\times 20$ magnification, XP. d Amphibole (ferropargasite, centre) inclusion in Sz 13/1 (×200, PPL). e-f Sz 13/2 (loner 3, stamped potsherd). e The fabric of Sz 13/2 in $\times 20$ magnification, XP. f Grog inclusions in Sz 13/2 (×100, PPL). On the left, "grog in grog" (second-generation grog) is displayed. $\mathbf{g}-\mathbf{h}$ The fabric of Sz 21 (loner 4 , grey-burnished bottle) in $\times 20(\mathrm{~g})$ and $\times 100(\mathrm{~h})$ magnification, $\mathrm{XP}$ 


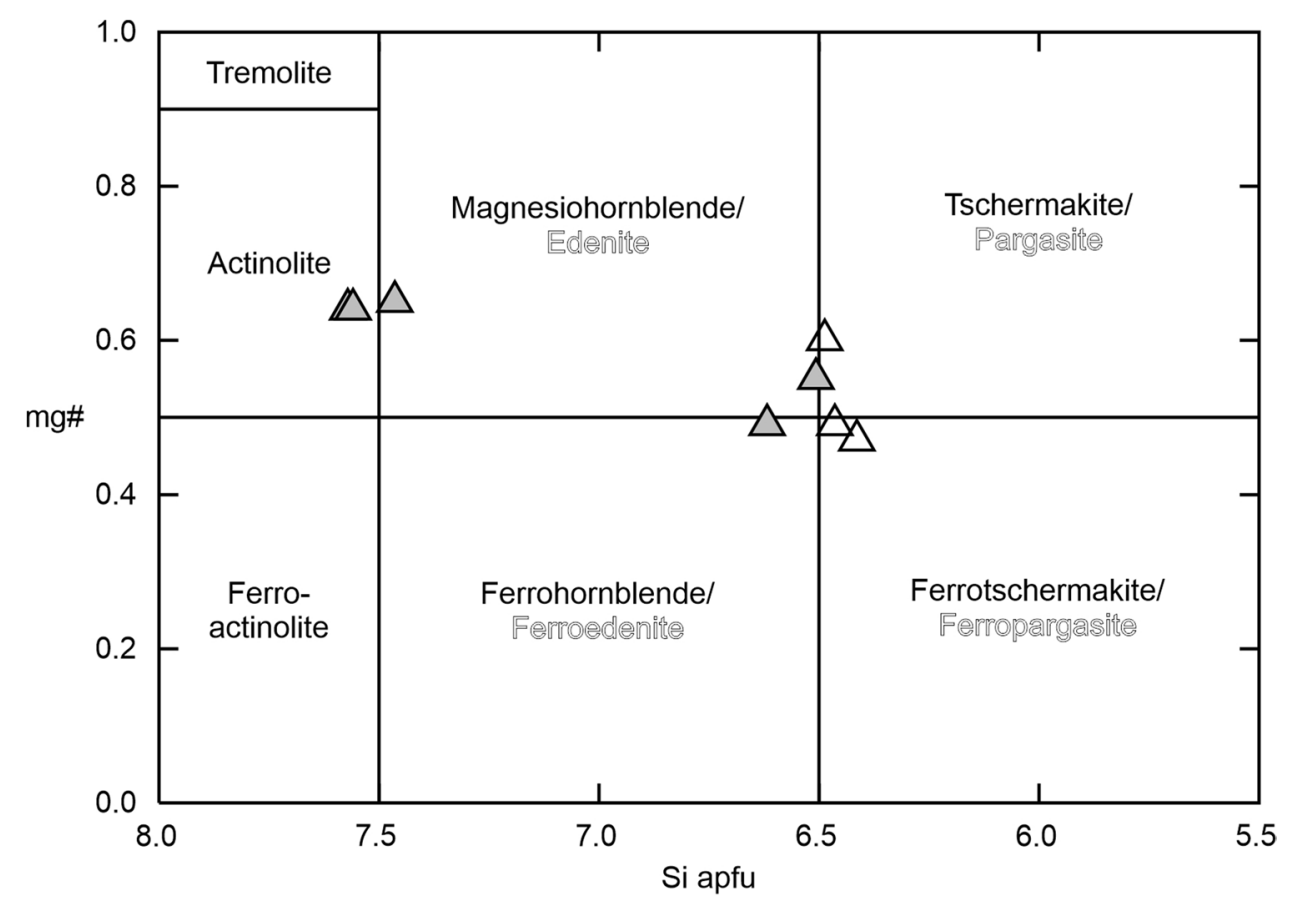

Fig. 6 Chemical composition of amphiboles in the Szólád 13/1 pottery based on the diagrams of Hawthorne and Oberti (2007). The measured grains are $\mathrm{Ca}-a m p h i b o l e s$ and $\mathrm{Na}-\mathrm{Ca}$-amphiboles, where further classification is based on $\mathrm{mg} \#(\mathrm{mg} \#=\mathrm{Mg}$ apfu/ $(\mathrm{Mg}$ apfu $+\mathrm{Fe}^{2+}$ ) apfu; apfu=atom per formula unit) and the $\mathrm{Si}$ apfu in the T-position of the general $\mathrm{AB}_{2} \mathrm{C}_{5} \mathrm{~T}_{8} \mathrm{O}_{22} \mathrm{X}_{2}$ amphibole formula. This diagram shows both amphibole types, as black names represent the endmembers of the Ca-amphibole system, while white names refer to the endmembers used in the Na-Ca-amphibole system. Similarly,

varieties) in the hinterland of the parental sediment. Several rock fragments consisting of quartz, K-feldspar, plagioclase, and biotite altering into chlorite are also present in the sample; these can be interpreted as of granitoid/metagranitoid origin (Fig. 8a-b). Garnets further support the presence of metamorphic rocks; however, they are not characteristic of specific rock types and can be associated with various medium- to high-grade metamorphites. The angularity of quartz grains varies throughout the sample from subangular to rounded, which also adds to the polymictic features.

Elemental compositions of the glass phase inclusions previously observed by OM were also measured (Supplementary Materials Table S9). These inclusions are predominantly completely spherical, although, sparsely, fragments with conchoidal fractures are also present (both shapes are displayed in Fig. 8a). However, based on their similar optical properties and chemical composition, it is presumed that the shards are different forms of the same glassy material; therefore, henceforward, these inclusions will be referred to as glass spherules throughout this study. The SEM-EDS analysis revealed that these glass spherules are primarily composed of $\mathrm{SiO}_{2}$; in most cases, it exceeds $90 \mathrm{wt} \%$ of the total composition; the full triangles are amphibole compositions where $\mathrm{Na}$ apfu $<0.5$ in the A-position (thus, are classified as Ca-amphiboles), while compositions displayed by empty triangles exceed this threshold (and classify as $\mathrm{Na}$-Ca-amphiboles). Despite the diversity of amphibole types present in the pottery, the measured grains can be classified into two major groups: a low-grade metamorphic one with an Al-rich actinolitic composition and a medium-grade metamorphic/igneous one (where $\mathrm{Na}$ apfu and $\mathrm{mg \#}$ fluctuates around 0.5 and $\mathrm{Si}$ apfu around $6.5)$

lowest value measured in the ceramic sample is $83.5 \mathrm{wt} \%$, while the highest is $100 \mathrm{wt} \%$. Concentric zonation can often be observed; however, no significant change in the composition connected to the zones was detected (Supplementary Materials Fig. S3); this feature may be related either to the presence of light elements (probably $\mathrm{C}$ and $\mathrm{H}$, or even $\mathrm{N}$ ) or trace elements, which cannot be measured by the instrument used. In addition to $\mathrm{SiO}_{2}$, a number of minor elements were occasionally detected in minor concentrations including $\mathrm{P}_{2} \mathrm{O}_{5}$ (2.59-7.13 wt\%), $\mathrm{Al}_{2} \mathrm{O}_{3}$ (1.57-4.23 wt\%), $\mathrm{FeO}(0.21-2.68$ wt $\%), \mathrm{CaO}(0.71-2.01 \mathrm{wt} \%), \mathrm{K}_{2} \mathrm{O}(0.26-0.45 \mathrm{t} \%)$, and $\mathrm{MgO}$ $(0.26 \mathrm{wt} \%)$. The origin of these glass spherules is not evident. In nature, glass phases are mainly connected to volcanic activities (e.g. volcanic glass, pyroclasts); however, even in the case of acidic volcanism, $\mathrm{SiO}_{2}$ content is unlikely to exceed $80 \mathrm{wt} \%$; additionally, unlike volcanic glass, these spherules do not contain primary crystallites at all. An artificial source, such as a by-product of glass making, can be ruled out as well owing to the high $\mathrm{SiO}_{2}$ and low or completely absence of $\mathrm{K}_{2} \mathrm{O}$ or $\mathrm{Na}_{2} \mathrm{O}$ content. Accordingly, based on the information available, an impact effect of a meteorite may be a possible explanation for the formation of glass spherules with such 
Fig. 7 Chemical composition of plagioclases in the Szólád $13 / 1$ pottery shown in ternary diagram after Greenwood and Earnshaw (1997). Intermediate (andesine-oligoclase) and sodic (albite) plagioclases are present, probably originating from different lithologies. Pure albite (with no detectable $\mathrm{Ca}$ or $\mathrm{K}$ ) and pure K-feldspar (with no detectable $\mathrm{Na}$ ) are also present in considerable quantities (not shown here, see Fig. $8 \mathrm{a}-\mathrm{b}$ )

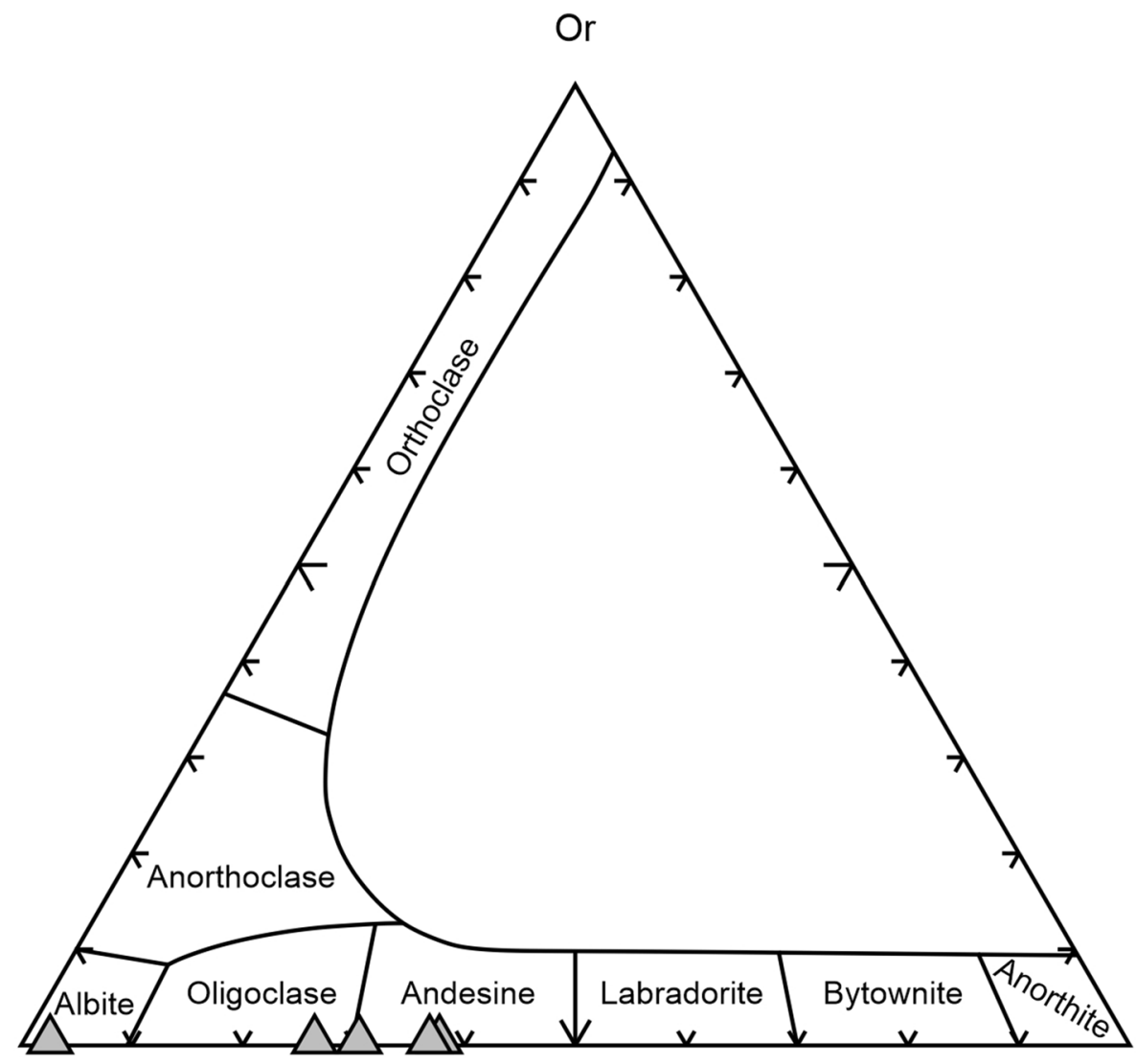

$\mathrm{Ab}$

An

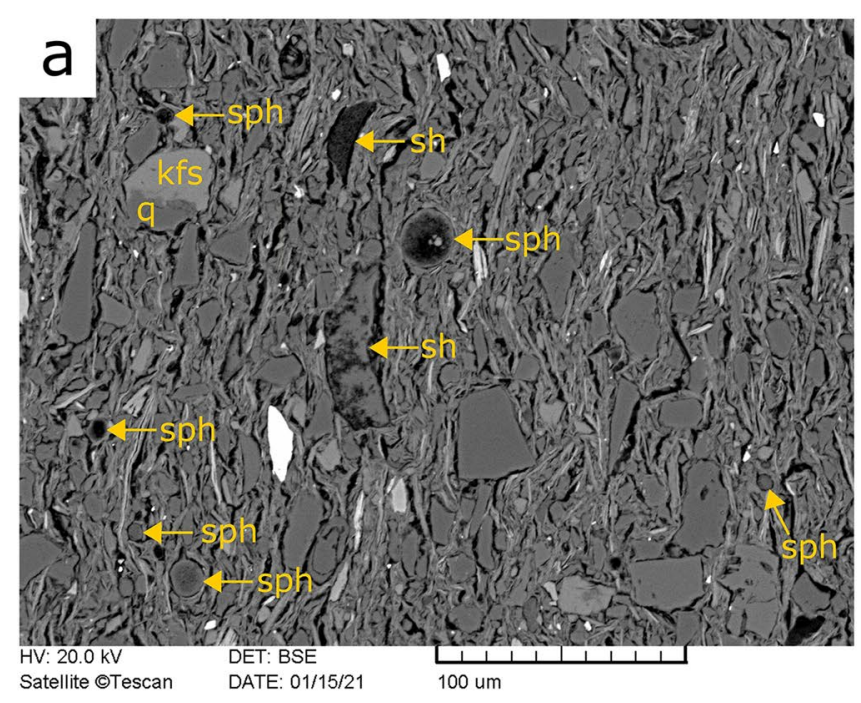

Fig. 8 Selected backscattered electron images of sample Sz 13/1. Abbreviations: $a b$ albite, $b t$ biotite, $c h l$ chlorite, $k f s$ K-feldspar, $p l$ plagioclase, $q$ quartz, $s h$ glass shard with conchoidal fracture, $s p h$ glass spherule, ttn titanite. a BSE image displaying glass spherules and glass shards and a granitoid rock fragment consisting of quartz and

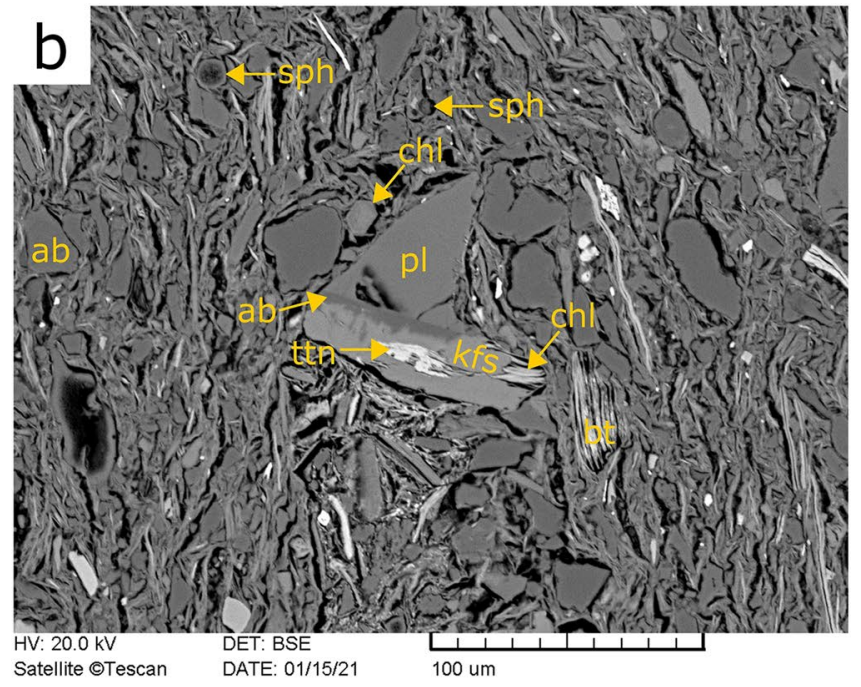

K-feldspar. b BSE image displaying a granitoid rock fragment consisting of plagioclase (andesine) and albitizing K-feldspar with titanite and chlorite; glass spherules, euhedral chlorite, altering biotite, and albite are marked in the image 
high $\mathrm{SiO}_{2}$ content, providing that the impact occurred at a geological formation with high $\mathrm{SiO}_{2}$ content (e.g. relatively pure quartz sandstone), resulting in the melting and then quick solidification (vitrification) of the original material (Claeys et al. 1992; French 1998; Simonson and Glass 2004; Johnson and Melosh 2012; Wittke et al. 2013). In this case, the newly formed, vitrified inclusions could scatter and be transported even as far as a few hundreds of kilometres from the point of the impact (known as the strewn field). Although a precise origin for these glass spherules has not been determined in the present study, they may nonetheless provide important information from which the source(s) of the raw materials used for Sz 13/1, and vessels of similar type, may ultimately be determined.

\section{Evaluation of the bulk elemental analysis}

Each sample was analysed by PGAA and NAA; the complete dataset is available in the Supplementary Materials (Table S1-S3). It must be noted that the concentration of $\mathrm{CaO}$ (and its substitute elements) is often skewed by secondary, post-depositional processes (Schwedt et al. 2004). However, the differences in $\mathrm{CaO}$ concentrations in the examined samples are supported with microscopic observations as well, where no signs of secondary carbonates were detected; therefore, $\mathrm{CaO}$ was not excluded from the statistical analysis.

The principal component analysis of the major elements shows that the individuals of the main fabric subgroups (FG 1A-C) do not pull apart significantly, as opposed to three loners (Sz 11/2, Sz 13/1, Sz 21), where major elemental compositions differ significantly (Fig. 9a). The sum of the variance of the first two principal component axes is
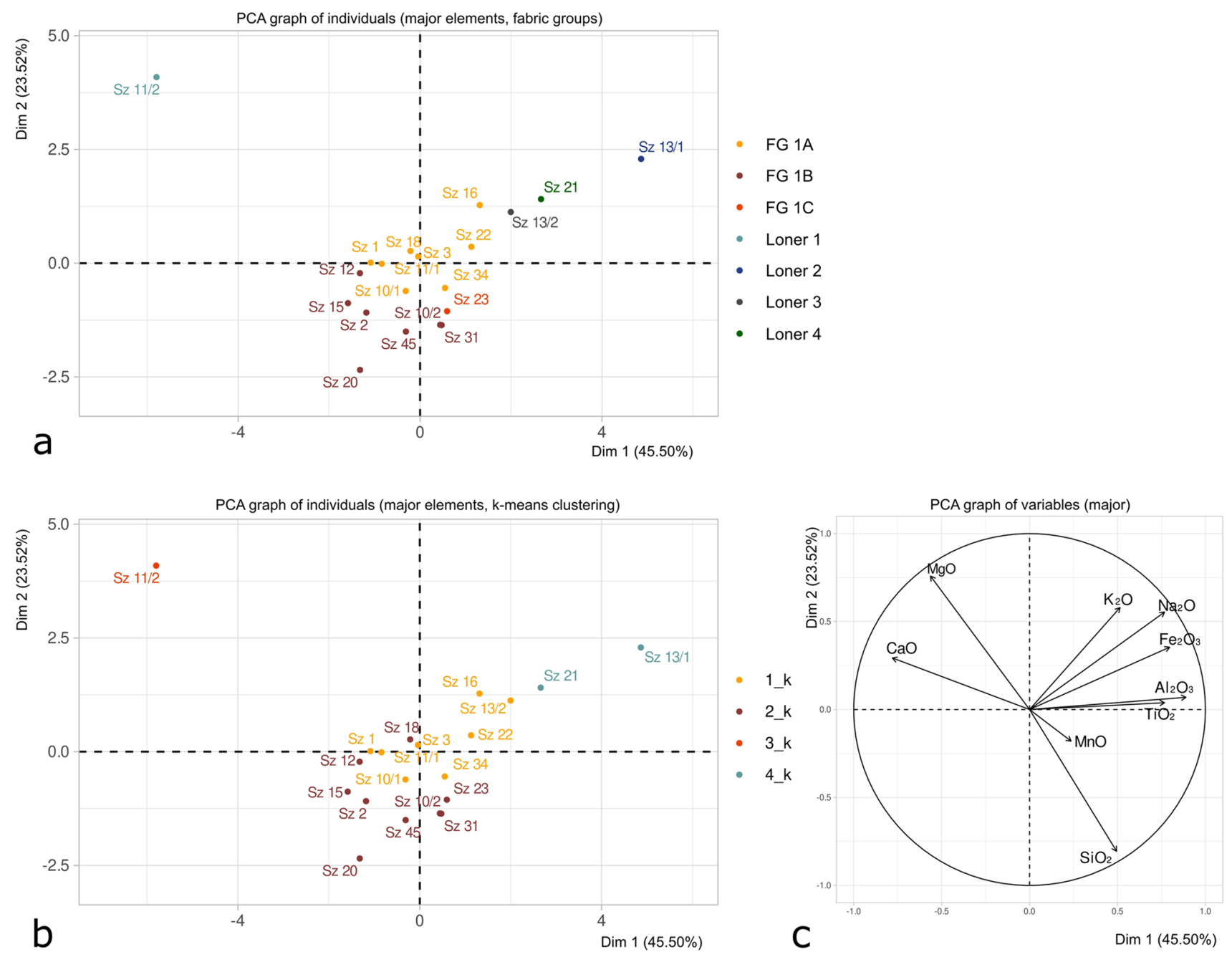

Fig. 9 Score (a-b) and loading plot (c) of the first two dimensions of the principal component analysis carried out on the major elemental data of each sample. A comparison between the fabric grouping by
OM (a) and automated grouping with $k$-means partitioning on PCA scores $(\mathbf{b})$ is presented 

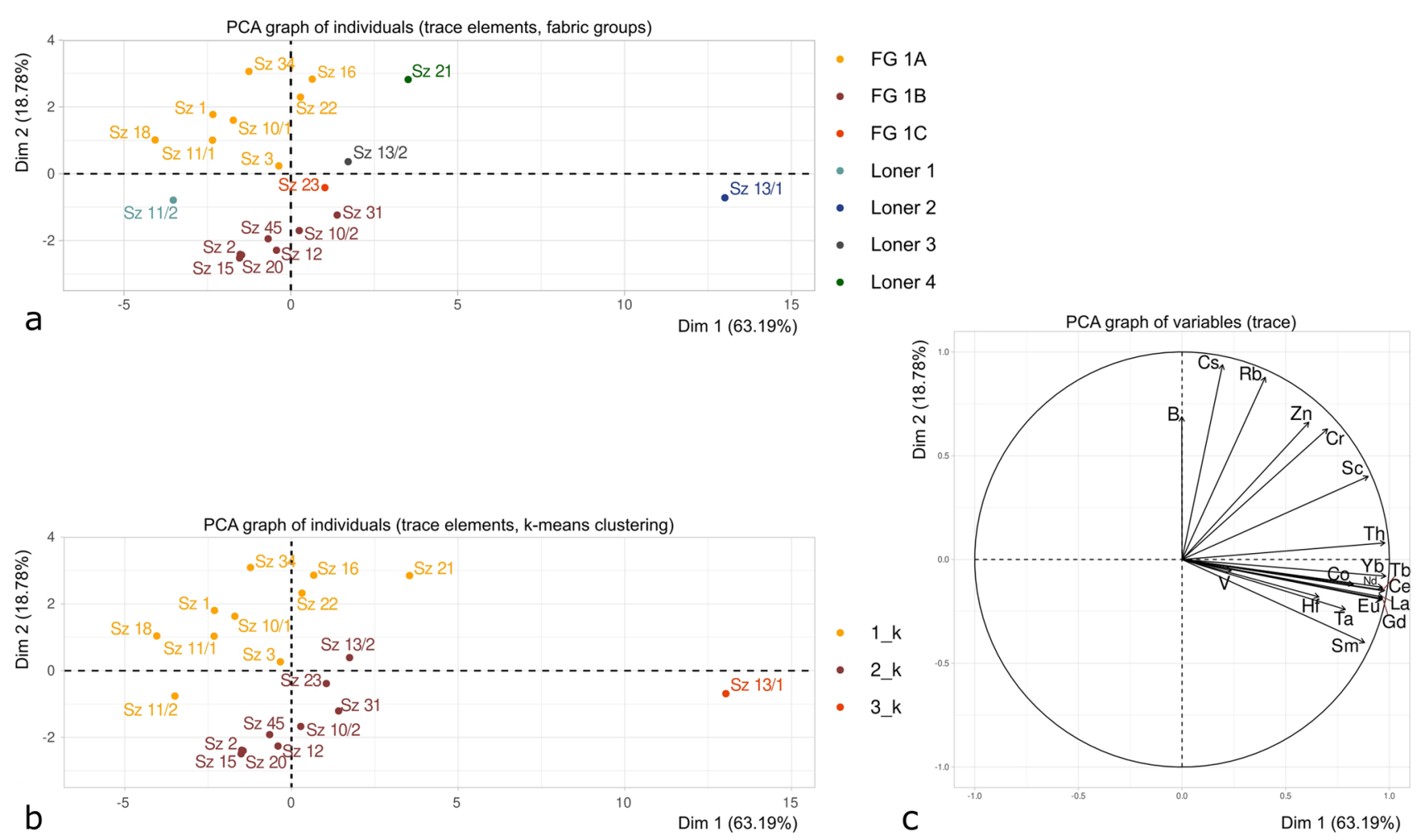

Fig. 10 Score (a-b) and loading plot (c) of the first two dimensions of the principal component analysis carried out on the minor and trace elemental data of each sample. A comparison between the fabric

relatively high (69\%), which suggests on the one hand the heterogeneity of the elements represented by the individual groups, and on the other, the validity of the statistical analysis. The most determinative variables of the first principal component axis (Dim. 1) were the concentrations of $\mathrm{Al}_{2} \mathrm{O}_{3}$, $\mathrm{Fe}_{2} \mathrm{O}_{3}, \mathrm{CaO}, \mathrm{Na}_{2} \mathrm{O}$, and $\mathrm{TiO}_{2}$ (Supplementary Materials Table S13). From this point of view, sample Sz 11/2 with the highest $\mathrm{CaO}$ and lowest $\mathrm{Al}_{2} \mathrm{O}_{3}$ concentration defines one end of the axis, while the $\mathrm{Al}_{2} \mathrm{O}_{3}, \mathrm{Na}_{2} \mathrm{O}$, and $\mathrm{Fe}_{2} \mathrm{O}_{3}$ concentrations in samples $\mathrm{Sz} 13 / 1$ and $\mathrm{Sz} 21$ define the other end. The second principal component axis (Dim. 2) is defined mainly by the concentrations of $\mathrm{SiO}_{2}$ and $\mathrm{MgO}$. In this case, $\mathrm{Sz} 11 / 2$ with the lowest $\mathrm{SiO}_{2}$ and highest $\mathrm{MgO}$ concentration represents one end of the axis, while samples belonging to FG 1 can be found at the other end. The high $\mathrm{CaO}$ and $\mathrm{MgO}$ content in $\mathrm{Sz}$ 11/2 can be readily connected to the predominant coarse calcite marble and dolomite inclusions present in the sample.

The principal component analysis carried out on the minor and trace element concentrations displays a slightly different image of the assemblage (Fig. 10a). The sum of the variance in this case is especially high (81.97\%), where the first principal component axis is mainly defined by rare earth elements and Th, while Dim. 2 is primarily characterised by $\mathrm{Cs}, \mathrm{Rb}, \mathrm{B}, \mathrm{Zn}$, and $\mathrm{Cr}$ grouping by $\mathrm{OM}$ (a) and automated grouping with $k$-means partitioning on PCA scores (b) is presented

(Fig. 10c, Supplementary Materials Table S18). According to this, sample $\mathrm{Sz} 13 / 1$ separates most significantly, as it contains higher concentration of almost each minor and trace element. A further difference that can be observed based on the minor and trace elements is that the fabric groups defined by OM (FG1A, B, and C) pull apart more, owing to the fact that the samples of FG1A were generally poorer in rare earth elements than those of FG1B. Taking into account that in the main fabric group we found mainly quartz, carbonates, feldspars, and mica, which minerals usually contain a low amount of trace elements,

Table 2 Comparison of chemical groups of major elements defined by $k$-means clustering and fabric groups defined by $\mathrm{OM}$

\begin{tabular}{lllll}
\hline Fabric groups & \multicolumn{4}{l}{ K groups (major) } \\
\cline { 2 - 5 } & $1 \_\mathrm{k}$ & $2 \_\mathrm{k}$ & $3 \_\mathrm{k}$ & $4 \_\mathrm{k}$ \\
\hline 1A & 7 & 1 & 0 & 0 \\
1B & 0 & 6 & 0 & 0 \\
1C & 0 & 1 & 0 & 0 \\
$\mathrm{Sz} \mathrm{11/2}$ & 0 & 0 & 1 & 0 \\
$\mathrm{Sz} \mathrm{13/1}$ & 0 & 0 & 0 & 1 \\
$\mathrm{Sz} \mathrm{13/2}$ & 1 & 0 & 0 & 0 \\
$\mathrm{Sz} \mathrm{21}$ & 0 & 0 & 0 & 1 \\
\hline
\end{tabular}


Table 3 Comparison of chemical groups of minor and trace elements defined by $k$-means clustering and fabric groups defined by OM

\begin{tabular}{llll}
\hline Fabric groups & \multicolumn{3}{l}{ K groups (trace) } \\
\cline { 2 - 4 } & $1 \_\mathrm{k}$ & 2_k & 3_k \\
\hline 1A & 8 & 0 & 0 \\
1B & 0 & 7 & 0 \\
1C & 0 & 1 & 0 \\
Sz 11/2 & 1 & 0 & 0 \\
Sz 13/1 & 0 & 0 & 1 \\
Sz 13/2 & 0 & 1 & 0 \\
Sz 21 & 1 & 0 & 0 \\
\hline
\end{tabular}

we speculate that the trace element contents of the studied ceramics are determined by the trace element content of the clays used and independent from the amount and type of temper added in fabric group 1. This suggests that somewhat different clays were used for the different type of vessels; however, proving this statement would require the application of further analytical techniques (e.g. SEM-WDS of ceramic matrix and further geological sampling), which exceed the scope of this paper. The relatively minor pulling apart of $\mathrm{FG} 1 \mathrm{~A}, 1 \mathrm{~B}$, and $1 \mathrm{C}$ in the trace element PCA score plots indicates that the differences in the chemical compositions connected to their raw material are not significant, suggesting that they might originate from separate layers of the same clay formation. In order to validate the fabric groups previously formed by OM analysis, $k$-means partitioning on both PCA scores was applied (Fig. 9b; Fig. 10b). Upon the partitioning, the optimal number of groups in the case of major elements was defined as four (Supplementary Materials Fig. S5). This grouping is in good agreement with the petrographic grouping (Table 2): the most striking outliers (Sz 11/2, Sz $13 / 1, \mathrm{Sz} 21$ ) form separate clusters from the main petrographic fabric group. FG 1 preserves the main structure of subgroups as separate clusters (1_k and 2_k); however, the sample that forms FG 1C, standing on the border of FG $1 \mathrm{~A}$ and FG 1B, falls into 2_k (corresponding with FG 1B).

As opposed to the $k$-means partitioning of the major elemental data (Fig. 10b), in the case of minor and trace elements, the optimal number of groups was three (Supplementary Materials Fig. S8). This is mainly caused by the fact that sample $\mathrm{Sz} 11 / 2$, the most visible outlier based on the major elemental composition, now falls in the group of 3_k (associated with FG 1A), along with $\mathrm{Sz} 21$. Sample 13/1, however, forms a separate cluster in this case, too. $k$-means groups $2 \_\mathrm{k}$ and 3_k agree with the $k$-means groups formed based on the major elements; 2_k is in good agreement with FG 1B, while 3_k corresponds with FG 1A (Table 3).

\section{Discussion}

\section{Local production}

As up to present day no pottery kilns have been found from sixth-century contexts in the territory of Transdanubia, only indirect evidence can indicate probable centres of local pottery production, such as through comparison of vessel fabrics with sediments present within the environs of archaeological sites (ca. $15 \mathrm{~km}$ radius).

Based on the petrographic analysis, one main fabric group was defined, in which three subgroups were further distinguished. The statistical analysis carried out on the bulk elemental data mainly supported this classification. Despite the fact that there are differences within the subgroups of FG 1 that can be detected by both OM and in the elemental composition (as displayed in Fig. 10a-b), the characteristic suite of minerals observed suggested that they might have been derived from the same geological environment, and the visible variation might be connected to using clays from different depositional sequences and/or different technological choices.

Each sample belonging to FG 1 contained rock fragments derived from sandstone with calcite cement; however, as a general rule, in FG 1A these fragments were more frequent than in FG 1B and $\mathrm{C}$. This type of sandstone is rather unique in Hungary; they belong to the Miocene (Pannonian) sandstones; however, up to the present day, no extensive petrographic studies have been published about them. The outcrop of such sandstone closest to Szólád is the Szamárkó ("donkey stone") that emerges ca. $12 \mathrm{~km}$ north-east of Szólád in the territory of Zamárdi; it is a greyish, Late Miocene Pannonian period carbonate-cemented sandstone of the Tihany Formation (Fig. 11a-b; Józsa et al. 2020). This type can be easily distinguished from the fine-grained quartz cemented "red" sandstone widely spread across the Balaton Highland, on the northern shore of lake Balaton (Balatonfelvidék Sandstone Formation, shown in Fig. 2), which was also exploited from prehistoric times (Péterdi 2012). The clasts that build up the Szamárkó sandstone are of polymictic origin; they are predominantly comprised of monocrystalline quartz of volcanic and metamorphic origin, polycrystalline quartz, and carbonate concretions; muscovite, plagioclase (often sericitic or saussuritic), K-feldspars (orthoclase as well as microcline, often perthitic), quartzite, chert, muscovite, graphite, and chlorite rich schists are common. Accessory minerals (zoisite, garnet, tourmaline, amphibole) can be found frequently. The igneous clasts are generally more angular compared to those of metamorphic origin. Owing to the similarities in the inclusion assemblages and the textural features, it seems likely that the carbonate-cemented sandstone fragments present in the pottery samples derived 

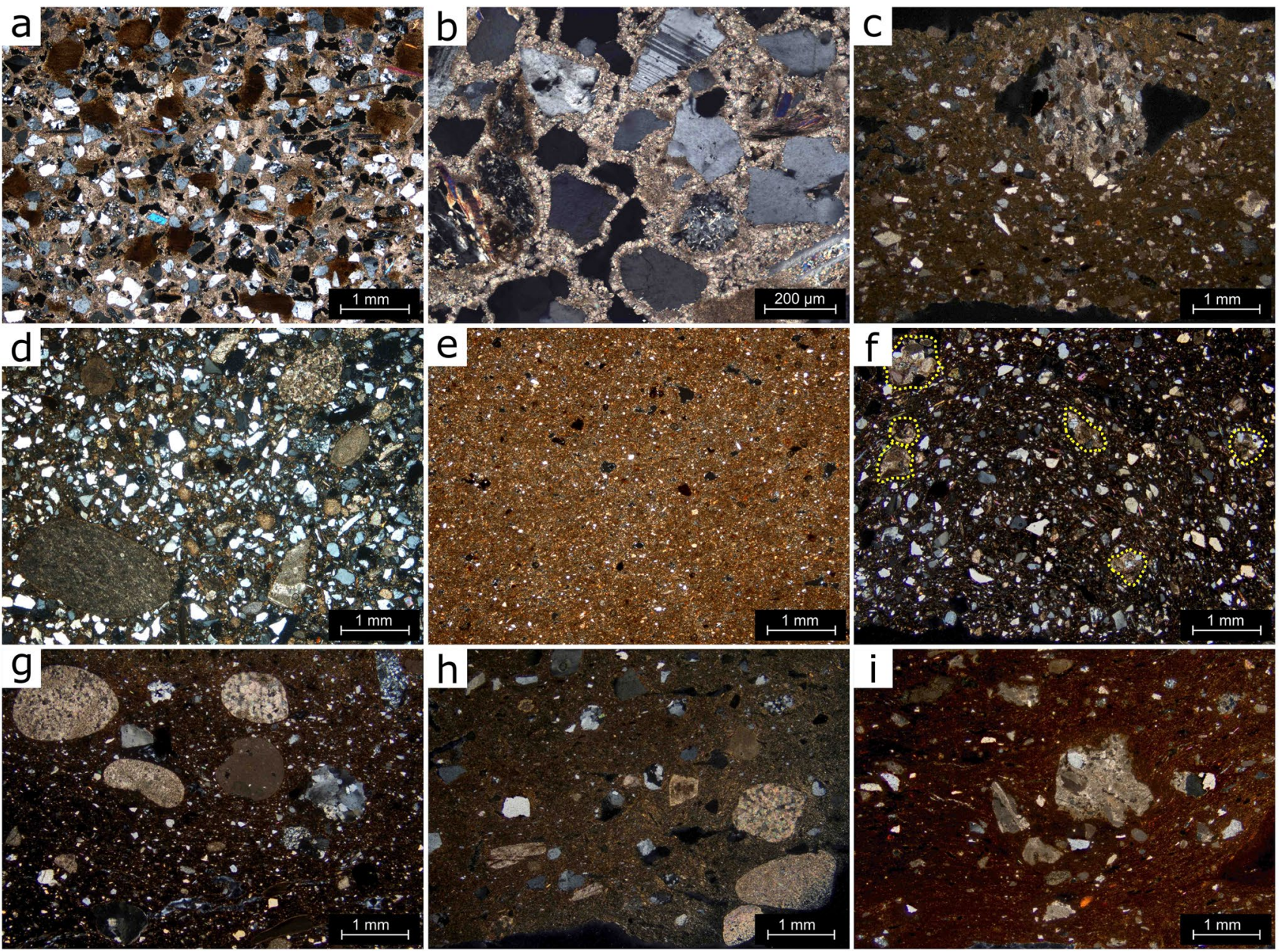

Fig. 11 Photomicrographs of local clay, local sandstone, and contemporaneous (fourth to sixth century) pottery samples from the vicinity of Szólád. All photos were taken with crossed polars. Photo credit: K. Bajnok. a-b Thin section photomicrograph of polymictic sandstone with carbonate cement from Zamárdi, Szamárkő, $\times 20$ (a) and $\times 100$ (b) (sampled by Dóra Kürthy, Kuny Domonkos Múzeum, Tata). c Thin section photomicrograph of a ceramic sample from the Langobard age settlement of Balatonlelle, showing coarse-grained sandstone fragments with carbonate cement, probably identical to the Szamárkő sandstone, $\times 20$ (unpublished MA thesis by K. Bajnok). d-e Thin section photomicrograph of coarse-grained (d) and fine-grained (e) fired local clays from Balatonszárszó, ca. 2 km from Szólád, × 20 (the sample is the property of Attila Kreiter, Hungarian National Museum, Budapest). $\mathbf{f}$ Thin section photomicrograph of a ceramic sample from the internal fortification of Keszthely-Fenékpuszta (fifth- to sixthcentury context), showing medium-grained sandstone fragments with carbonate cement, probably identical to the Szamárkő sandstone, $\times 20$ (sampled by K. Bajnok, unpublished). g Thin section photomicrograph of a ceramic sample from the internal fortification of Ságvár (fourth-century context), showing a fabric similar to FG $1 \mathrm{~B}, \times 20$ (sampled by K. Bajnok, unpublished). h Thin section photomicrograph of a ceramic sample from the fifth- to sixth-century settlement of Zamárdi, showing coarse-grained sandstone fragments with carbonate cement, probably identical to the Szamárkő sandstone, $\times 20$ (photo: K. Bajnok, unpublished). i Thin section photomicrograph of a ceramic sample from the fifth- to sixth-century settlement of Ordacsehi, showing a fabric similar to FG $1 \mathrm{~B}, \times 20$ (unpublished MA thesis by K. Bajnok)

Balatonszárszó clays in order to compare them with the Szólád FG 1 samples (Fig. 11d). This local sediment showed good agreement with FG 1B regarding its mineral composition and the size and shape of the inclusions: very coarse sand-sized (up to $2 \mathrm{~mm}$ ), well-rounded dolomite with microsparry and plastic groundmass, limestone, carbonate concretions, and chert dominate the coarse fraction, with few carbonate-cemented sandstone fragments. The finer fraction $(<0.5 \mathrm{~mm})$ is dominated by monocrystalline quartz, biotite, limonite and chlorite rich schist/quartzite, 
quartz sandstone, typically sericitic and saussuritic plagioclase, orthoclase, microcline, and additionally, finer versions of the coarse inclusions are also present, along with few mollusc shells and single crystals of calcite. Accessory minerals are frequently found, mainly zoisite, garnet, tourmaline, and epidote. These inclusions are in a muscovite-rich marly clay with few biotite fragments. According to Kreiter and Pánczél, during the experimental briquette preparation, it became clear that this sediment did not contain enough clay for the forming of pottery, and therefore, if it was exploited, it required the addition of another fatter clay, such as the one also present locally (Fig. 11e). However, it is possible that the same set of inclusions was available locally in loose sand as well, which was deliberately added as temper to a fatter clay. Using this type of raw material in this chronological period is not limited to Szólád: characteristics of both FG $1 \mathrm{~A}$ and $1 \mathrm{~B}$ (and 1C being a transitional fabric between the former ones) were observed among the vessels of the neighbouring fifth- to sixth-century settlements (Fig. 1), such as Balatonlelle (Fig. 11c), Zamárdi (Fig. 11h), Ordacsehi (Fig. 11i), the late Roman internal fortifications of Keszthely-Fenékpuszta (Fig. 11f), and Ságvár (Fig. 11g) (Pánczél-Bajnok et al. 2014). This does not necessarily suggest that a single pottery centre produced vessels for all these settlements, especially as there are technological and stylistic differences between the pottery from these sites, but rather reflects on what was available locally. In reviewing the information presented above, it appears plausible that FG 1 represents the locally available raw material that was exploited to produce the majority of the vessels found in the cemetery of Szólád.

Contrasting the local fabric variants with the stylistic typology, we find that every vessel defined as a deep bowl (Schale) belongs to FG 1A, whereas almost each closed hole-mouth jar (Kumpf) was made with the coarser-grained FG 1B variant; two exceptions are Sz 16 and 34, which, despite being Kumpfs, were made from the finer 1A fabric. Furthermore, $\mathrm{Sz} 23,31$, and 45 can be defined as more simplified, roughly made versions of the deep bowls; however, they were made out of the coarser $1 \mathrm{~B}$ and the transitional $1 \mathrm{C}$ fabrics. This suggests deliberate choices in clay paste recipes that were applied during the production of the two different styles of vessels. Based on the microscopic analysis, most probably each subgroup of FG 1 was intentionally tempered with loose alluvial sand, although some characteristics present in the fabric (i.e. occasional streaks and argillaceous lumps) might suggest clay mixing as well (Ho and Quinn 2021). However, it is important to emphasise that variegated clays-that are commonly found around Szólád connected to the Tihany Formation (Sztanó et al., 2013)—might show similar patterns when not homogenised sufficiently. Nevertheless, it remains possible that instead of (or in addition to) adding loose aplastic inclusions as temper to a naturally fine-grained clay, two (or more) clays with different characteristics may have been mixed. Either way, from a more anthropological point of view, clay mixing and tempering share the fundamental intention of manipulating the paste properties by changing the ratio and grain-size distribution of aplastic inclusions.

Intentional differences in paste recipes between deep bowls and closed hole-mouth jars might reflect on the function of the vessels. Although, having been found in burials, the function of these vessels might differ from those found in settlement contexts, yet, the coarser fraction in the FG $1 \mathrm{~B}$ recipe resulted in more open porosity, therefore better thermal shock resistance, which is desirable for cooking pots. Additionally, the large carbonate inclusions with similar thermal expansion as the clay matrix are optimal for preventing stress within the body during use (Eramo 2020). As opposed to Kumpfs, the finer grained, less porous deep bowls might suggest that the more elaborate deep bowls were tablewares, and their main function was to contain either solids or liquids. In each vessel belonging to FG 1, traces of hand-forming (most probably coil-building) were detected macroscopically; however, more detailed analytical study (e.g. following the methodologies summarised by Thér (2020)) was beyond the scope of this study. The surface of deep bowls was smoothed/low-burnished in each case, and additionally, in those closed hole-mouth jars that belong to FG 1A, traces of such surface treatment were also observed. Contrary to $1 \mathrm{~A}$, no sign of surface treatment on the pots in FG 1B was observed.

Differences in the firing can also be observed between the subgroups of FG 1. Samples belonging to FG 1A have a lighter, light to medium brown colour in hand specimen as well as in PPL, suggesting dominantly oxidising conditions during firing; however, the occasional changes in colour within the samples are indicative of not entirely controlled firing processes. Their clay matrix displays high to moderate optical activity, which suggests that during firing the maximum temperature did not exceed $850{ }^{\circ} \mathrm{C}$ (Quinn 2013). Additionally, biotite clasts within these samples typically show strong to moderate pleochroism and red to dark brown colour with normal cleavages, which is more typical in pots fired below $800{ }^{\circ} \mathrm{C}$ (Travé Allepuz 2021). The presence of carbonates with sharp boundaries and almost no sign of thermal combustion also confirms the low firing temperature. In contrast to 1A, samples in FG 1B display dark medium grey or greyish brown matrices, or a black, completely isotropic matrix. Within the samples, the colours do not typically change, although in some samples ( $\mathrm{Sz} \mathrm{20,Sz} \mathrm{31,} \mathrm{Sz} \mathrm{45)} \mathrm{a}$ thin layer of red indicates a partially oxidising atmosphere. However, macroscopically it is visible that there are slight changes in colour throughout the pots, suggesting that the firing processes were not fully controlled in this case either. 
Their clay matrix shows weak to no optical activity, whereas biotite clasts usually display weaker pleochroism and darker colour with more open cleavages. Carbonates vary within the samples, occasionally showing diffuse boundaries and altered matrix. These observations indicate that in this fabric subgroup, vessels were fired at higher temperatures than those in FG 1A; however, the maximum temperature did not likely exceed $900{ }^{\circ} \mathrm{C}$. Regarding the firing practice, $\mathrm{Sz} 23$ (belonging to FG 1C) shares similarities with FG $1 \mathrm{~B}$.

\section{Further possibly locally made vessels}

Although sample $\mathrm{Sz}$ 11/2 was distinguished as a loner and was not included in the main local fabric group, some information indicates that it may have been produced in the vicinity of Szólád. While the fine fraction of the fabric does not entirely match any of the samples in FG 1, the characteristic minerals present in the coarse fabric - apart from the marble inclusions - are referring to the same geological environment as described in FG 1: the sandstone with carbonate cement, the large, rounded dolomite, quartzite, and chert inclusions suggest that the pot might have been manufactured in the area close to Szólád, perhaps exploiting a different clay source. The mollusc shell fragments present are also suggestive of an origin close to lake Balaton (Fig. 5a-b). However, based on major elemental composition (Fig. 9), this sample plots significantly apart from others owing to its extremely high $\mathrm{Ca}$ and $\mathrm{Mg}$ content, yet this separation is not obvious looking at the trace elemental data (Fig. 10); in fact, the automated grouping by $k$-means partitioning grouped this sample together with those belonging to FG 1A (Fig. 10b). This further confirms the relation of this sample with the local production.

The most distinctive element in this sample is the deliberate addition of marble fragments. This suggests that for this sample, two separate tempers of different origin were used: a well-rounded, loose alluvial sand temper and intentionally crushed, angular rock fragments. Whereas the added sand appears to be local, there is no natural geological source of marbles within the close vicinity of the examined site, which strongly suggests that the marbles were present locally in forms of building stones, funerary and votive monuments, and other marble objects and were re-used as temper in pottery production. This paste recipe was in fact popular for the making of several types of cooking pots in the late Roman period, as has been reported by several researchers. In some studies, it was interpreted as the secondary use of marble artefacts (Dellmour 1989; Flügel et al. 2004; Pánczél-Bajnok et al. 2014; Maritan et al. 2021), while other authors described sparry calcite temper (Kern 2011; Fazioli 2012; Herold 2016). Specifying that the sparry calcite fragments in the ceramic fabric are indeed marble fragments is not always possible. However, when the fragments are indicative of being intentionally crushed beforehand, furthermore, polycrystalline calcites are present, accessory minerals can be detected in them occasionally, and especially if such forms of calcites do not match with the local geology, the authors argue for being more likely that such temper indicates the deliberate (re)use of marble.

Determining the provenance of archaeological marble artefacts usually requires a combination of analytical techniques. Moreover, identifying the source of marble is further complicated if the inclusions are crushed, since calcites more often crack along cleavage planes rather than by the grain boundaries; therefore, it is difficult to reconstruct fabric characteristics and grain shapes. Moreover, firing might influence their appearance or isotopic values (Flügel et al. 1997; Leno et al. 2010; Maritan et al. 2021). Determining the origin of the marble fragments in the Szólád vessel with such methods is beyond the scope of this current article; instead, we would like to introduce the most probable sources. In the Imperial period, the exploitation of marble quarries in the east Alpine region was extensive, providing either standardised prefabricates or end products for different local or regional markets. According to Djurić and Müller (2009), the most common Alpine marbles in Pannonia were those from Pohorje (Slovenia) and Gummern (Austria). In the territory of Pannonia, there is only one source that can be described as marble. In Polgárdi (ca. $50 \mathrm{~km}$ to the east from Szólád), a crystalline limestone with some zones that underwent contact metamorphism owing to the thermal effect of cryptic magmatic intrusion below the limestone can be found. In these zones, based on its properties, the crystalline limestone can be considered white marble (Horváth and Ódor 1989; Gyalog and Horváth 2004), which might have been exploited during the Roman era (Simon 2003). Based on the handful of marble grains present, the marble in the Szólád sample is coarse-grained, and the maximum grain size of this marble was at least $2.5 \mathrm{~mm}$. The grain boundaries were only possible to observe in one grain, where a heteroblastic, mortar texture was displayed. The marble grains commonly contain accessory minerals, such as pyroxene (diopside) and quartz. Based on this information, none of the quarries mentioned above can be excluded, although the Alpine marbles appear to be more probable as, in the case of the Polgárdi crystalline limestone, the typical grain size is a few hundred $\mu \mathrm{m}$, while the maximum grain size published is $1700 \mu \mathrm{m}$ (Zöldföldi et al. 2004), and the marble zones in the crystalline limestone consist of almost exclusively pure calcites. In contrast to that, both the Pohorje (Jarc et al., 2010) and the Gummern (Prochaska 2021) marbles have coarser grain size, and pyroxenes can be found commonly in them as accessory minerals. On a more historical tangent, it might be worth noting that the definition of marble in Roman times was not necessary equivalent to modern geological definitions (e.g. differences between crystalline limestone and 
marble); therefore, one has to take this into account when investigating possible sources.

Apart from the temper choice, further slight differences distinguish this pot from other Kumpfs from Szólád. Although it was also made with a hand building technique, the surface is more carefully smoothed than the other similar pots. The completely black cores and the uniform, very thin, layer of buff colour on the surface suggests that a reducing atmosphere dominated the firing, which was finished with a short oxidising phase. This is indicative of well-controlled firing processes.

Although, among the Szólád vessels, only one is tempered with marble, such pots were commonly found in other fifth- to sixth-century archaeological sites in Pannonia, as reported briefly by Pánczél-Bajnok and co-workers (2014), and the same fashion was widespread in other former Roman territories too (Maritan et al. 2021). However, the Szólád pot remains unique, as the majority of these pots are different types of late Roman cooking pots, whereas stylistically this one is a closed hole-mouth jar (Kumpf), an archaic "Elbe Germanic" type that in Szólád is associated with the vessels belonging to FG 1B. Moreover, marble temper in the other contemporaneous cooking pots is always exclusive or predominant, while in this case, two types of temper of different origins were added to the clay paste. Such conscious choices suggests that there was an intention to incorporate Roman traditions into more "Germanic" pottery practices. Whether it was merely a choice based on fashion, or whether re-using one of the most characteristic materials of Roman imperialism had a more symbolic or cultural significance, cannot be determined through the petrographic results.

Sample Sz 13/2 was the only incomplete vessel in the cemetery; only a small potsherd of ca. $5 \mathrm{~cm}^{2}$ with traces of stamped decoration and a polished surface was left from the original pot. The fabric of this potsherd differs from the main fabric group; the most distinctive features (such as the Szamárkő type sandstone) are not present in the fabric, while this is the only pot tempered with grog. Despite the differences, in the PCA of the elemental data, this sample does not pull apart significantly from the FG 1 samples; moreover, the $k$-means partitioning groups it together with them (Figs. 9-10). Based on this information, it cannot be ruled out that this vessel was also produced out of similar raw materials; however, no characteristic mineralogical fingerprint of the place of manufacture was observed.

The petrographic analysis suggests that during the preparation of the raw clay, processes connected to the sorting of the aplastic inclusions (such as sieving, levigation) were incomplete, or left out entirely, and that then grog was added to the poorly sorted paste. With regard to firing techniques, the pot was fired to medium greyish brown colour, indicating that the atmosphere was not completely oxidising during the procedure, or that organic matter occurred in the clay.
The maximum firing temperature most probably exceeded $750{ }^{\circ} \mathrm{C}$, based on the few decomposed or partially decomposed carbonate particles, while the optical activity suggests that it did not exceed $850{ }^{\circ} \mathrm{C}$ (Quinn 2013).

Up to present day, very few petrographic studies have been published about pottery with stamped decoration, which was a popular and distinctive style of this region in the sixth century. According to results from the large-scale pottery production centre at the Roman town of Cibalae (now Vinkovci, Croatia) in south Pannonia, vessels with stamped decoration were all made of very fine, well-prepared clay, while grog temper was not observed among the pottery at all (Roksandić, 2018). There are many unresolved questions about the scale and places of production of this vessel type, requiring further analysis; however, it is presumable that this style was produced in a number of places across Pannonia, and local variants with separate paste recipes might have been developed.

\section{Import wares}

The analysis of the Thuringian cup (Sz 13/1) confirmed the initial hypothesis, based on its style, that it was produced in a more distant territory. In the PCA of the elemental data, this sample was the most removed from other samples. Due to the lack of possible local reference materials, known kiln sites, or further analogous samples analysed by ceramic petrography from the same stylistic group, it was not possible to identify the clay source; however, certain characteristics of the utilised clay were observed, indicative of the geological environment from which it was derived. The petrographic and SEM-EDS analyses revealed that the clay contained fragments from multiple rock types, including greenschist and amphibolite facies, and further fragments of possibly granitoid/metagranitoid origin. The common presence of amphiboles and occasional pyroxenes-considering that they weather easily and do not transport far after erosion (Velbel 2007) - suggests that the geological source from where these inclusions originate is relatively close in a geological sense to the clay deposit that was utilized for this vessel. From archaeological analogies, this vessel type was most frequently found in territory of the former Thuringian Kingdom, and the petrographic results support that the place of manufacture might be connected to the Bohemian Massif, where these rock types occur close to each other. Furthermore, the glass spherules identified in the clay might be linked to a meteoritic impact event. In this case, the strewn field of the Miocene Ries crater in Nördlingen might be a possible explanation for the presence of these spherules (Artemieva et al. 2002; Trnka and Houzar 2002; Řanda et al. 2008; Brachaniec et al. 2014). 
For the making of this cup, the utilised clay was most probably cleaned, resulting in a moderately sorted paste with inclusions below very fine sand size. Occasional large iron-rich nodules suggest that the homogenisation of the raw material was not complete. No sign of artificially added temper was detected in the fabric, which suggests that the amount of aplastic inclusions present made the clay plastic enough for throwing this small, thin-walled cup on a potter's wheel, which action is also indicated by the strong rilling marks on the interior surface of the vessel. The exterior was then burnished all over the surface and decorated with pattern burnishing. The rather sharp change of colour from light brown to light greyish brown observed in the cross-section of the sample (Fig. 5c) suggests a change in atmosphere during firing; however, from the outside, the colour of the surface is uniform, which is indicative of a well-controlled firing process. Based on the high optical activity of the matrix, this vessel was fired below $850{ }^{\circ} \mathrm{C}$. In addition, the unaltered green amphiboles present in the sample (Fig. 5d) suggest that the maximum firing temperature was even lower, and did not exceed $750{ }^{\circ} \mathrm{C}$ (Quinn 2013).

The grey, pattern burnished, spouted bottle ( $\mathrm{Sz} 21)$ was made of a well-prepared clay. The very well-sorted, siltsized inclusions suggest levigation, or similar clay preparation process. Seldom carbonised or completely burnt out organic (plant) residues can be found in the fabric; this might have been added deliberately in order to achieve greyer colour during the firing, but the amount added did not result in a highly porous structure, which would not have been desirable for liquid containers. Moreover, the technological choice of burnishing makes the surface of the pot harder and denser, which improves its liquid keeping properties (Ionescu and Hoeck 2020). The bottle was mainly shaped on a potter's wheel, except for the handle, which was hand-formed and attached to the ceramic body subsequently. Despite the dark grey surface colour, the brownish grey core of this vessel is indicative of at least partially oxidising atmosphere, and the grey colour was achieved by the presence of organic material (soothing). Based on the high optical activity of the matrix, this vessel was fired in a relatively low temperature $\left(<800{ }^{\circ} \mathrm{C}\right)$. This information is in agreement with the general view of burnished wares being low-fired (von Dassow 2009).

As the mineralogical composition of this vessel was not indicative of any distinct geological environment, the petrographic analysis did not narrow down significantly the possible places of manufacture. Grey-burnished pottery was particularly popular in fourth- to fifth-century Pannonia and in the neighbouring Barbaricum and is usually thought to be distributed regionally (Hárshegyi and Ottományi 2013). There are a handful of workshops known from this period where this style was produced, such as Pilismarót (Ottományi, 1996), Leányfalu (Ottományi,
1991), Balatonaliga (Bónis, 1994), Savaria/Szombathely (Ottományi and Sosztarics, 1998), and Cibalae/Vinkovci (Rapan Papeša and Roksandić, 2016), and several further workshops are presumed without the evidence of kiln sites. However, up to the present day, only Cibalae/Vinkovci is known to be actively producing grey-burnished wares in the sixth century. Based on some preliminary petrographic results published by Roksandić (2018, p. 149), the fabric of the Szólád sample appears to be similar to sample 1 of Vinkovci. Further petrographic and geochemical characterisation of the local Vinkovci material is needed for the examination of whether the Szólád bottle might be a product of a Cibalae pottery workshop; however, the existing information does not contradict this theory.

\section{Concluding remarks}

Our research shows that the majority of pots buried in the cemetery of Szólád (samples of FG 1) was produced by exploiting local sediments. During the production sequence, differences in technological choices were observed for stylistically different pots, i.e. for deep bowls and closed hole-mouth jars. These dissimilarities might be explained by distinct functions, e.g. deep bowls might have been more appropriate for containing liquids or other goods, while the coarser-grained jars might have been used as cooking pots. Furthermore, for the shaping of the more elaborate deep bowls, finer clay was desirable. These intentional technological choices suggest that the production was organised for this community; professional potter(s) provided these ancient vessels locally. Previous genetic studies (Alt et al. 2014; Amorim et al. 2018) confirmed that the majority of the deceased buried with either deep bowls or closed hole-mouth jars are males of central/ northern European genetic ancestry, which corresponds with the stylistic parallels of these types that were most widely spread in modern south and central Germany, and south Moravia. Each one of these vessels is hand-formed; however, this does not necessarily equal poorer quality, but rather suggests that they were not produced at a large-scale pottery centre. Given the consistent technological sequence that is indicative of experienced craftsmanship, it is possible that choosing a hand-building technique for production was not primarily because of the lack of knowledge of other techniques, but rather a deliberate choice. Providing that the potter was in fact a member of this highly mobile community buried at Szólád, hand-building techniques are more compatible with a mobile lifestyle, whereas wheel-throwing requires a more settled pottery workshop centre. Although there are further contemporaneous sites where the same local material was utilised (as explained in the "21" section and shown in Fig. 11), that does not 
necessarily mean that they were all produced in the same workshop. Examining the connections with regard to pottery production between the known fifth- to sixth-century settlements and cemeteries in Transdanubia is the subject of ongoing research.

A variant of closed hole-mouth jars was identified in sample $\mathrm{Sz} 11 / 2$, which appears to have been produced in a similar geological environment as characterised by FG 1; however, the addition of marble temper distinguishes this vessel from other Kumpfs. This technological choice might reflect a Roman fashion popular in the fifth to sixth century in many former provinces, but it might as well refer to having been produced in a different workshop. Further, stylistically more obvious Roman provincial traditions can be identified in the grey, burnished, spouted bottle $(\mathrm{Sz}$ 21 , which might have been produced in a south Pannonian workshop. Although, upon the petrographic analysis, it was not yet possible to narrow down the production area, future ceramic studies on pottery from the possible production sites might be able to determine the origin of this vessel as well.

In grave 13, two unique vessels were found; while according to our analysis, the Thuringian cup (Sz 13/1) points towards distant territories (most likely towards the territory of the former Thuringian kingdom), stamped vessels were developed locally in sixth-century Pannonia and became the dominant vessel type in the later Italian Langobard phase. In this sense, old and new traditions merge in this burial. Further elements also suggest the differentiated status of the individual in grave 13, such as a weighting scale, the remains of a horse, and the fact that this is the deepest grave in the cemetery (Vida et al. 2017). The presence of the Thuringian cup in the cemetery, far away from where it was produced, might reflect economic activities (import) or other types of exchange between these regions as well as the cup having potentially "travelled with its owner".

This first petrographic and geochemical analysis of Langobard age pottery from Transdanubia sheds light to a mobile community where ancient barbarian traditions were practiced continuously ("Elbe Germanic" type vessels produced locally) and new fashions were picked up (stamped vessel), while local provincial elements (grey, burnished bottle) indicate relationships with remaining provincial people. However, preliminary data about comparisons of fifth- to sixth-century cemeteries and settlement sites (Pánczél-Bajnok et al. 2014) suggest that at settlements, late Roman pottery was more abundant. This raises caution for the consideration that grave goods in cemeteries might be selective to certain aspects of life, and they do not necessarily reflect what was used in everyday life.
Supplementary Information The online version contains supplementary material available at https://doi.org/10.1007/s12520-021-01467-1.

Acknowledgements The authors are most grateful to Sándor Józsa (Department of Petrology and Geochemistry, Eötvös Loránd University, Budapest) for his advice during the petrographic analysis. For permission to use samples of the Szamárkő sandstone and the local sediments from Balatonszárszó, we cordially thank Dóra Kürthy (Kuny Domonkos Múzeum, Tata) and Attila Kreiter (Hungarian National Museum, Budapest). We kindly thank the reviewers for their help in improving our manuscript.

Funding Open access funding provided by ELKH Wigner Research Centre for Physics.

\section{Declarations}

Conflict of interest The authors declare no competing interests.

Open Access This article is licensed under a Creative Commons Attribution 4.0 International License, which permits use, sharing, adaptation, distribution and reproduction in any medium or format, as long as you give appropriate credit to the original author(s) and the source, provide a link to the Creative Commons licence, and indicate if changes were made. The images or other third party material in this article are included in the article's Creative Commons licence, unless indicated otherwise in a credit line to the material. If material is not included in the article's Creative Commons licence and your intended use is not permitted by statutory regulation or exceeds the permitted use, you will need to obtain permission directly from the copyright holder. To view a copy of this licence, visit http://creativecommons.org/licenses/by/4.0/.

\section{References}

Alt KW, Knipper C, Peters D, Müller W, Maurer A-F, Kollig I, Nicklisch N, Müller C, Karimnia S, Brandt G, Roth C, Rosner M, Mende B, Schöne BR, Vida T, von Freeden U (2014) Lombards on the move - an integrative study of the migration period cemetery at Szólád. Hungary Plos ONE 9:e110793. https://doi.org/10.1371/journal.pone.0110793

Amorim CEG, Vai S, Posth C, Modi A, Koncz I, Hakenbeck S, La Rocca MC, Mende B, Bobo D, Pohl W, Baricco LP, Bedini E, Francalacci P, Giostra C, Vida T, Winger D, von Freeden U, Ghirotto S, Lari M, Barbujani G, Krause J, Caramelli D, Geary PJ, Veeramah KR (2018) Understanding 6th-century barbarian social organization and migration through paleogenomics. Nat Commun 9:3547. https://doi.org/10.1038/s41467-018-06024-4

Artemieva N, Pierazzo E, Stöffler D (2002) Numerical modeling of tektite origin in oblique impacts: implication to Ries-Moldavites strewn field. Bull Geosci 77:303-311

Bocsi Z (2008) Die Keramik aus zwei spätantiken Siedlungen am Balaton: Ordacsehi-Kis-töltés und Zamárdi-Kútvölgyi-dûlő, Komitat Somogy, Ungarn, in: Bemmann, J., Schmauder, M. (Eds.), Kulturwandel in Mitteleuropa. Langobarden, Awaren, Slawen. Akten der Internationalen Tagung in Bonn vom 25. bis 28. Februar 2008, Kolloquien zur Vor- und Frühgeschichte. R. Habelt, Bonn, pp. 415-430

Bóna I (1956) Die Langobarden in Ungarn. Acta Archaeol Acad Sci Hung 66:183-244 
Bóna IB, Horváth J (2009) Langobardische Gräberfelder in WestUngarn, Monumenta Germanorum Archaeologica Hungariae. Magyar Nemzeti Múzeum, Budapest.

Bónis É (1994) Császárkori telep Balatonaligán (Siedlung aus der Kaiserzeit in Balatonaliga). Veszpr Megyei Múzeumok Közleményei 19(20):157-176

Brachaniec T, Szopa K, Karwowski Ł (2014) Discovery of the most distal Ries tektites found in Lower Silesia, southwestern Poland. Meteorit Planet Sci 49:1315-1322. https://doi.org/10. 1111/maps. 12311

Budai T, Chikán G (2001) Magyarország Földtani Térképe L-33-48 Balatonfüred. Magyarország fedett földtani térképe 1:100 000. Magyar Állami Földtani Intézet, Budapest.

Budai T, Császár G, Csillag G, Dudko A, Koloszár L, Majoros G (1999) A Balaton-felvidék földtana: magyarázó a Balatonfelvidék földtani térképéhez, 1:50 000 - Geology of the Balaton Highland. Explanation to the Geological Map of the Balaton Highland, 1:50 000, Occasional papers of the Geological Institute of Hungary. Magyar Állami Földtani Intézet, Budapest.

Burkhard M (1993) Calcite twins, their geometry, appearance and significance as stress-strain markers and indicators of tectonic regime: a review. J Struct Geol 15:351-368. https://doi.org/10. 1016/0191-8141(93)90132-T

Claeys P, Casier J-G, Margolis SV (1992) Microtektites and mass extinctions: evidence for a Late Devonian asteroid impact. Science 257:1102-1104. https://doi.org/10.1126/science.257.5073. 1102

Csáky V, Gerber D, Koncz I, Csiky G, Mende BG, Szeifert B, Egyed B, Pamjav H, Marcsik A, Molnár E, Pálfi G, Gulyás A, Kovacsóczy B, Lezsák GM, Lőrinczy G, Szécsényi-Nagy A, Vida T (2020) Genetic insights into the social organisation of the Avar period elite in the 7th century AD Carpathian Basin. Sci Rep 10:948. https://doi.org/10.1038/s41598-019-57378-8

De Corte F, van Sluijs R, Simonits A, Kučera J, Smodiš B, Byrne AR, De Wispelaere A, Bossus D, Frána J, Horák Z, Jaćimović R (2001) Installation and calibration of Kayzero-assisted NAA in three Central European countries via a Copernicus project. Appl Radiat Isot 55:347-354. https://doi.org/10.1016/S0969-8043(01) 00063-X

Dellmour R (1989) Keramikanalyse mit dem Polarisationsmikroskop. Methodik - Interpretation - Beispiele. Archaeol Austriaca 73:17-34

Djurić B, Müller HW (2009) White Marbles in Noricum and Pannonia: an outline of the Roman quarries and their products, in: Jockey, P. (Ed.), Levkos Lithos. Marbres et Autres Roches de La Méditerranée Antique : Études Interdisciplinaires / Interdisciplinary Studies on Mediterranean Ancient Marble and Stones. Proceedings of the VIIIth International Conference of the Association for the Study of Marble and Other Stones Used in Antiquity (ASMOSIA), Collection l'atelier Méditerranéen. Paris, pp. $111-128$

Droberjar E (2008) Thüringische und langobardische Funde und Befunde in Böhmen. Zum Problem der späten Phasen der Völkerwanderungszeit, in: Bemmann, J., Schmauder, M. (Eds.), Kulturwandel in Mitteleuropa. Langobarden, Awaren, Slawen. Akten Der Internationalen Tagung in Bonn Vom 25. Bis 28. Februar 2008, Kolloquien Zur Vor- Und Frühgeschichte. R. Habelt, Bonn, pp. $229-248$

Eramo G (2020) Ceramic technology: how to recognize clay processing. Archaeol Anthropol Sci 12:164. https://doi.org/10.1007/ s12520-020-01132-z

Fazioli KP (2012) Keramikanalyse mit dem Polarisationsmikroskop. Methodik - Interpretation - Beispiele. Arheol Vestn 63:199-234
Flügel C, Joachimski M, Flügel E (1997) Römische Keramik mit Marmormagerung: Herkunftstimmung mit Hilfe von stabilen Isotopen (Auerbergtöpfe aus Süddeutschland). Archäol Korresp 27:265-284

Flügel Ch, Flügel E, Häusler W, Joachimski M, Koller J, Baumer U, Wagner U (2004) Roman Coarse Ware from Bavaria, Austria and Northern Italy. Hyperfine Interact 154:231-251. https://doi.org/ 10.1023/B:HYPE.0000032026.86222.b0

Freeden U von, Vida T, Winger D (2020) Fremde Freunde? Archäologie und Naturwissenschaften. Fragestellungen zum langobardzeitlichen Gräberfeld von Szólád, Ungarn, in: Meyer, C., Held, P., Knipper, C., Nicklisch, N. (Eds.), Der Zahn Der Zeit - Mensch Und Kultur Im Spiegel Interdisziplinärer Forschung. Festschrift Für Kurt W. Alt, Veröfferntlichungen Für Archäologie Sachsen-Anthalt - Landesmuseum Für Vorgeschichte. Landesamt für Denkmalpflege und Archäologie Sachsen-Anthalt, Landesmuseum für Vorgeschichte, Halle an der Saale, pp. 99-112

Freeden U. von (2008) Ausgewählte Befunde aus dem langobardenzeitlichen Gräberfeld von Szólád, Komitat Somogy, in: Bemmann, J., Schmauder, M. (Eds.), Kulturwandel in Mitteleuropa Langobarden - Awaren - Slawen. Akten der Internationalen Tagung in Bonn vom 25. bis 28. Februar 2008, Kolloquien zur Vor- und Frühgeschichte. Deutsches Archäologisches Institut. Römisch-Germanische Kommission, Rheinisches Landesmuseum Bonn, Universität Bonn. Institut für Vor- und Frühgeschichtliche Archäologie, pp. 399-413.

French BM (1998) Traces of catastrophe: a handbook of shock-metamorphic effects in terrestrial meteorite impact structures. LPI Contribution No. 954, Lunar and Planetary Institute, Houston

Gméling K, Simonits A, Sziklai László I, Párkányi D (2014) Comparative PGAA and NAA results of geological samples and standards. J Radioanal Nucl Chem 300:507-516. https://doi.org/10. 1007/s 10967-014-3032-2

Goetz HW, Jarnut J, Pohl W (2003) Regna and Gentes. The relationship between Late Antique and Early Medieval peoples and kingdoms in the transformation of the Roman world, The transformation of the Roman world. Brill, Leiden, Boston

Greenwood NN, Earnshaw A (1997) Chemistry of the elements. Elsevier Butterworth-Heinemann, Oxford

Gyalog L, Horváth I (eds) (2004) A Velencei-hegység és a Balatonfó földtana / Geology of the Velence Hills and the Balatonfö. Magyar Állami Földtani Intézet, Budapest

Gyalog L (ed) (2005) Magyarázó Magyarország fedett földtani térképéhez (az egységek rövid leírása) 1: 100 000. MÁFI, Budapest

Hakenbeck S (2011) Roman or barbarian? Shifting identities in early medieval cemeteries in Bavaria. Post-Class Archaeol 1:37-66

Hárshegyi P, Ottományi K (2013) Imported and local pottery in late Roman Pannonia. Late Antiq Archaeol 10:471-528. https://doi. org/10.1163/22134522-12340040

Hawthorne FC, Oberti R (2007) Classification of the amphiboles. Rev Mineral Geochem 67:55-88. https://doi.org/10.2138/rmg.2007. 67.2

Heather P (2007) The fall of the Roman Empire. Oxford University Press, Oxford, A new history of Rome and the barbarians

Herold H (2016) Spätantike und Frühmittelalter - eine technologische Kontinuität? Analysen zu Funden aus Michelstetten (Niederösterreich), in: Csécs, T., Takács, M. (Eds.), Beatus Homo Qui Invenit Sapientiam. Ünnepi Kötet Tomka Péter 75. Születésnapjára. Lekri Group Kft, Győr

Ho JWI, Quinn PS (2021) Intentional clay-mixing in the production of traditional and ancient ceramics and its identification in thin section. J Archaeol Sci Rep 37:102945. https://doi.org/10.1016/j. jasrep.2021.102945 
Horváth I, Ódor L (1989) A Polgárdi Mészkő Formáció kontakt metamorf és metaszomatikus jelenségei. Magy. Állami Földt. Intéz. Évi Jelentése 137-143

Ionescu C, Hoeck V (2020) Ceramic technology. How to investigate surface finishing. Archaeol Anthropol Sci 12:204. https://doi.org/ 10.1007/s12520-020-01144-9

Jarc S, Maniatis Y, Dotsika E, Tambakopoulos D, Zupancic N (2010) Scientific characterisation of the Pohorje marbles, Slovenia. Archaeometry 52:177-190. https://doi.org/10.1111/j.1475-4754. 2009.00476.x

Johnson BC, Melosh HJ (2012) Impact spherules as a record of an ancient heavy bombardment of Earth. Nature 485:75-77. https:// doi.org/10.1038/nature10982

Józsa S, Szakmány G, Miklós DG, Varga A (2020) A törmelékes üledékek és kőzetek petrográfiai vizsgálati eredményei a Kárpát-Pannon térség kutatásában: a magyar kutatók hozzájárulása az elmúlt 150 évben. Földt. Közlöny 150, 291-291. https://doi. org/10.23928/foldt.kozl.2020.150.2.291

Kayzero [WWW Document], 2021. URLhttp://www.kayzero.com/ k0naa/k0naaorg/Nuclear_Data_SC/Nuclear_Data_SC.html. Accessed 3 Nov 2021

Kern A (2011) Interdisziplinäre archäometrische Untersuchungen frühgeschichtlicher Keramiken des Burgenlandes (BSc thesis). Universität Wien, Vienna

Kern A (2013) Langobardenzeitliche Siedlungsstrukturen im Burgenland anhand zweier Fallbeispiele (MA thesis). Universität Wien, Vienna

Knipper C, Koncz I, Ódor JG, Mende BG, Rácz Z, Kraus S, van Gyseghem R, Friedrich R, Vida T (2020) Coalescing traditionscoalescing people: community formation in Pannonia after the decline of the Roman Empire. PLoS ONE 15:e0231760. https:// doi.org/10.1371/journal.pone.0231760

Koncz I (2015) 568 - a historical date and its archaeological consequences. Acta Archaeol Acad Sci Hung 66:315-340. https://doi. org/10.1556/072.2015.66.2.4

Koncz I (2019) For a genetic comparison: cemeteries of three fifth-century communities in Pannonia, in: Giostra, C. (Ed.), Migrazioni, Clan, Culture: Archeologia, Genetica e Isotopi Stabili: III Incontro per l'archeologia Barbarica, Milano, 18 Maggio 2018, Archeologica Barbarica. SAP, Società archeologica s.r.l, Mantova, pp. 53-68

Kreiter A, Pánczél P (2013) Balatonszárszó-Kis erdei dúlő lelőhely kerámia anyagából kiemelt edénytípusainak vizsgálata (Unpublished report). Hungarian National Museum, Archaeology Database.

Kreiter A, Marton T, Gomart L, Oross K, Pánczél P (2017) Looking into houses: analysis of LBK ceramic technological change on a household level, in: Burnez-Lanotte, L. (Ed.), Matières à Penser. Raw Materials Acquisition and Processing in Early Neolithic Pottery Productions / Sélection et Traitement Des Matières Premières Dans Les Productions Potières Du Néolithique Ancien. Proceedings of the Workshop of Namur (Belgium), 29-30 May 2015, Séances de La Société Préhistorique Française. Société préhistorique française, Paris, pp. 111-132

Leno V, Zöldföldi J, Taubald H (2010) Änderung der $\delta 180$ und $\delta 13 \mathrm{C}$ Isotopenverhältnisse verschiedener Marmorsorten in Abhängigkeit der Brenntemperatur, in: Hahn, O., Hauptmann, A., Modarressi-Tehrani, D., Prange, M. (Eds.), Archäometrie Und Denkmalpflege 2010, Jahrestagung Im Deutschen Bergbau-Museum. Deutsche Mineralogische Gesellschaft, Bochum, pp. 1-3

Maritan L, Ganzarolli G, Antonelli F, Rigo M, Kapatza A, Bajnok K, Coletti C, Mazzoli C, Lazzarini L, Vedovetto P, Chavarría Arnau A (2021) What kind of calcite? Disclosing the origin of sparry calcite temper in ancient ceramics. J Archaeol Sci 129:105358. https://doi.org/10.1016/j.jas.2021.105358

Montana G (2020) Ceramic raw materials: how to recognize them and locate the supply basins-mineralogy, petrography.
Archaeol Anthropol Sci 12:175. https://doi.org/10.1007/ s12520-020-01130-1

Ottományi K (1991) Későrómai kerámia a leányfalui ôrtoronyból (Die Keramik von Burgus in Leányfalu). Stud Com 22:5-144

Ottományi K (1996) Eine Töpferwerkstatt der spätrömischen Keramik mit Glättverzierung in Pilismarót-Malompatak. Acta Archaeol Acad Sci Hung 48:71-133

Ottományi K (2020) Late Roman pottery from Room III/North at the Visegrád-Gizellamajor fort. Acta Archaeol Acad Sci Hung 71:15-70. https://doi.org/10.1556/072.2020.00002

Ottományi K, Sosztarics O (1998) Spätrömische Töpferofen in südlichen Stadteil von Savaria. Savaria 23(3):145-216

Ottományi K (2009) Eingeglättete Gefässe aus der letzten Periode der Siedlung von Budaörs, in: Ex Officina ... : Studia in Honorem Dénes Gabler. Mursella Régészeti Egyesület, Győr, pp. 411-442

Pánczél-Bajnok K, Pánczél P, Szakmány G, Vida T (2014) 5-6. századi, Pannonia területéről származó kerámiák archeometriai elemzése / Archeometric analysis of 5-6th century ceramics from Pannonia. Archeometriai Múh. XI/1, 1-12

Papageorgiou I (2020) Ceramic investigation: how to perform statistical analyses. Archaeol Anthropol Sci 12:210. https://doi.org/10. 1007/s12520-020-01142-x

Péterdi B (2012) Balatonőszöd - Temetői dúlő rézkori lelőhely homokkő nyersanyagú kőeszközeinek kőzettani és geokémiai vizsgálata / Petrographical and geochemical investigation of stone tools made of sandstone from the site Balatonőszöd Temetôi dúlő (Hungary). Archaeom. Múh. IX/4, 265-286

Prochaska W (2021) The challenge of a successful discrimination of ancient marbles (part II): a databank for the Alpine marbles. J Archaeol Sci Rep 38:102958. https://doi.org/10.1016/j.jasrep. 2021.102958

Quinn PS (2013) Ceramic petrography: the interpretation of archaeological pottery \& related artefacts in thin section. Archaeopress, Oxford

Rácz Z, Vida T (2018) Germánok keletről és nyugatról: A gepidák és langobardok régészete / Germanen von Osten und Westen: Die Archäologie der Gepiden und Langobarden. 7000 Év Története: Fejezetek Magyarország Régészetéből / 7000 Jahre Geschichte: Einblicke in Die Archäologie Ungarns. Verlag Bernhard Albert Greiner, Remshalden, pp 189-210

Řanda Z, Mizera J, Frána J, Kučera J (2008) Geochemical characterization of moldavites from a new locality, the Cheb Basin, Czech Republic. Meteorit Planet Sci 43:461-477. https://doi.org/10. 1111/j.1945-5100.2008.tb00666.x

Rapan Papeša A, Roksandić D (2016) Cibalae/Vinkovci during Late Antiquity (fifth to sixth century AD) - new insights about old assumptions, in: Bugarski, I., Heinrich-Tamáska, O., Ivaniševic, V., Syrbe, D. (Eds.), GrenzÜbergänge. Spätrömisch, Frühchristlich, Frühbyzantinisch Als Kategorien Der Historisch-Archäologischen Forschung an Der Mittleren Donau / Late Roman, Early Christian, Early Byzantine as Categories in HistoricalArchaeological Research on the Middle Danube, Forschungen Zu Spätantike Und Mittelalter. Verlag Bernhard Albert Greiner, Remshalden, pp. 145-159.

Révay Z (2009) Determining elemental composition using prompt $\gamma$ activation analysis. Anal Chem 81:6851-6859. https://doi.org/ $10.1021 / \mathrm{ac} 9011705$

Révay Zs, Belgya T, Molnár GL (2005) Application of Hypermet-PC in PGAA. J Radioanal Nucl Chem 265:261-265. https://doi.org/ 10.1007/s10967-005-0818-2

Révay Z (2006) Calculation of uncertainties in prompt gamma activation analysis. Nucl. Instrum. Methods Phys. Res. Sect. Accel. Spectrometers Detect. Assoc. Equip., Proceedings of the 4th 
International k0-Users Workshop 564, 688-697. https://doi.org/ 10.1016/j.nima.2006.04.016

Rhé G, Fettich N (1931) Jutas und Öskü: zwei Gräberfelder aus der Völkerwanderungszeit in Ungarn mit einem anthropologischen Anhang von L. Bartucz, Skythika. Seminarium Kondakovianum, Prague

Roksandić D (2018) Vinkovci u kasnorimskom razdoblju - keramika kao pokazatelj života u kasnorimskim Cibalama / Vinkovci in late Roman period - pottery as an indicator of life in late Roman Cibalae, Vinkovci. ed, Acta Musei Cibalensis. Gradski muzej Vinkovci

Roux V (2019) Ceramics and society: a technological approach to archaeological assemblages. Springer International Publishing, Cham. https://doi.org/10.1007/978-3-030-03973-8

Schuh C, Makarewicz CA (2016) Tracing residential mobility during the Merovingian period: an isotopic analysis of human remains from the Upper Rhine Valley. Germany Am J Phys Anthropol 161:155-169. https://doi.org/10.1002/ajpa.23017

Schwedt A, Mommsen H, Zacharias N (2004) Post-depositional elemental alterations in pottery: neutron activation analyses of surface and core samples. Archaeometry 46:85-101. https://doi. org/10.1111/j.1475-4754.2004.00145.x

Simon H (2003) A polgárdi mészkőbányák története / History of limestone quarries in Polgárdi, Hungary, in: Szakáll, S., Fehér, B. (Eds.), A Polgárdi Szár-Hegy Ásványai / Minerals of the Szár Hill, Polgárdi, Hungary, Topographia Mineralogica Hungariae. Herman Ottó Múzeum, Miskolc, pp. 19-28

Simonits A, Östör J, Kálvin S, Fazekas B (2003) HyperLab: a new concept in gamma-ray spectrum analysis. J Radioanal Nucl Chem 257:589-595. https://doi.org/10.1023/A:1025400917620

Simonson BM, Glass BP (2004) Spherule layers-records of ancient impacts. Annu Rev Earth Planet Sci 32:329-361. https://doi.org/ 10.1146/annurev.earth.32.101802.120458

Szentmiklósi L (2018) Fitting special peak shapes of prompt gamma spectra. J Radioanal Nucl Chem 315:663-670. https://doi.org/ 10.1007/s10967-017-5589-z

Szentmiklósi L, Párkányi D, Sziklai-László I (2016) Upgrade of the Budapest neutron activation analysis laboratory. J Radioanal Nucl Chem 309:91-99. https://doi.org/10.1007/s10967-016-4776-7

Szentmiklósi L, Kis Z, Maróti B, Horváth LZ (2021) Correction for neutron self-shielding and gamma-ray self-absorption in promptgamma activation analysis for large and irregularly shaped samples. J Anal at Spectrom. https://doi.org/10.1039/D0JA00364F

Szilágyi V, Gyarmati J, Tóth M, Taubald H, Balla M, Kasztovszky Zs, Szakmány Gy (2012) Petro-mineralogy and geochemistry as tools of provenance analysis on archaeological pottery: study of Inka Period ceramics from Paria. Bolivia J South Am Earth Sci 36:1-17. https://doi.org/10.1016/j.jsames.2011.11.001

Sztanó O, Magyar I, Szónoky M, Lantos M, Müller P, Lenkey L, Katona L, Csillag G (2013) A Tihanyi Formáció a Balaton környékén: típusszelvény, képződési körülmények, rétegtani jellemzés / Tihany Formation in the surroundings of Lake Balaton: type locality, depositional setting and stratigraphy. Földt Közlöny 143:73-98

Tejral J (1985) Spätrömische und völkerwanderungszeitliche Drehscheibenkeramik in Mähren. Archaeologia Austriaca 69:105-145

Tejral J (2005) Zur Unterscheidung des vorlangobardischen und elbgermanisch-langobardischen Nachlasses, in: Pohl, W., Erhard, P. (Eds.), Die Langobarden. Herrschaft Und Identität, Forschungen Zur Geschichte Des Mittelalters. Verlag der Österreichischen Akademie der Wissenschaften, Vienna, pp. 103-200

Tejral J (2011) Langobardische Gräberfelder in Mähren. Archäologisches Institut der Akademie der Wissenschaften der Tschechischen Republik, Brno, Spisy Archeologického ústavu av ČR Brno
Thér R (2020) Ceramic technology. How to reconstruct and describe pottery-forming practices. Archaeol Anthropol Sci 12:172. https://doi.org/10.1007/s12520-020-01131-0

Travé Allepuz E (2021) Colour transformation and textural change in biotite: some remarks for the interpretation of firing technology in greyware pottery thin-sections. Minerals 11:428. https://doi. org $/ 10.3390 / \min 11040428$

Trnka M, Houzar S (2002) Moldavites: a review. Bull Geosci 77:283-302

Vai S, Brunelli A, Modi A, Tassi F, Vergata C, Pilli E, Lari M, Susca RR, Giostra C, Baricco LP, Bedini E, Koncz I, Vida T, Mende BG, Winger D, Loskotová Z, Veeramah K, Geary P, Barbujani G, Caramelli D, Ghirotto S (2019) A genetic perspective on Longobard-Era migrations. Eur J Hum Genet 27:647-656. https://doi. org/10.1038/s41431-018-0319-8

Velbel MA (2007) Chapter 4 Surface textures and dissolution processes of heavy minerals in the sedimentary cycle: examples from pyroxenes and amphiboles, in: Mange, M.A., Wright, D.T. (Eds.), Heavy minerals in use, developments in sedimentology. Elsevier, pp. 113-150. https://doi.org/10.1016/S0070-4571(07)58004-0

Vida T (2009) Local or foreign Romans? The problem of the Late Antique population of the 6th-7th centuries AD in Pannonia. In: Quast D (ed) Foreigners in Early Medieval Europe: Thirteen International Studies on Early Medieval Mobility, Monographien Des Römisch-Germanischen Zentralmuseums. Verlag des Römisch-Germanischen Zentralmuseums, Mainz, pp 233-259

Vida T (2011) Die Zeit zwischen dem 4. und dem 6. Jahrhundert im mittleren Donauraum aus archäologischer Sicht. In: Konrad M, Witschel C (eds) Römische Legionslager in Den Rhein- Und Donauprovinzen - Nuclei Spätantik-Frühmittelalterlichen Lebens?, Bayerische Akademie Der Wissenschaften München, Philosophisch- Historische Klasse: Abhandlungen; Neue Folge. Bayerische Akademie der Wissenschaften, München, pp 615-648

Vida T, Alt KW, Knipper C, Skriba P, Winger D, Freeden U von (2017) A multidisciplinary study on the Langobard period cemetery of Szólád in Pannonia. Hung Archaeol 46-62

Vida T (2008) Aufgaben und Perspektiven der Langobardenforschung in Ungarn nach István Bóna, in: Bemmann, J., Schmauder, M. (Eds.), Kulturwandel in Mitteleuropa: Langobarden, Awaren, Slawen : Akten Der Internationalen Tagung in Bonn Vom 25. Bis 28. Februar 2008, Kolloquien Zur Vor- Und Frühgeschichte. Habelt, Bonn, pp. 343-362

von Dassow S (2009) Low-firing and burnishing. Herbert Press. A \& C Black Publishers Ltd., London

von Hessen O (1968) Die langobardische Keramik aus Italien. Franz Steiner Verlag, Wiesbaden

von Freeden U, Vida T (2007) Ausgrabung des langobardenzeitlichen Gräberfeldes von Szólád, Komitat Somogy, Ungarn : Vorbericht und Überblick über langobardenzeitliche Besiedlung am Plattensee. Germania 85:359-384

von Freeden U, Winger D (2018) A langobardok „,vándorlása”: a szóládi temetô tanulságai / Die „Wanderung” der Langobarden: Erkenntnisse aus dem Gräberfeld von Szólád. In: Heinrich-Tamáska O, Winger D (eds) 7000 Év Története: Fejezetek Magyarország Régészetéből / 7000 Jahre Geschichte: Einblicke in Die Archäologie Ungarns. Verlag Bernhard Albert Greiner, Remshalden, pp 211-220

Werner J (1962) Die Langobarden in Pannonien: Beiträge zur Kenntnis der langobardischen Bodenfunde vor 568. Verlag der Bayerischen Akademie der Wissenschaften, Munich, Bayerische Akademie der Wissenschaften / Philosophisch-Historische Klasse; Neue Folge

Whitbread IK (1986) The characteristation of argillaceous inclusion in ceramic thin sections. Archaeometry 28:79-88. https://doi.org/ 10.1111/j.1475-4754.1986.tb00376.x 
Whitbread IK (1995) Greek transport amphorae: a petrological and archaeological study, Fitch Laboratory occasional paper. British School at Athens, London

Wickham C (2005) Framing the Early Middle Ages: Europe and the Mediterranean, 400-800. Oxford University Press, Framing the Early Middle Ages

Wittke JH, Weaver JC, Bunch TE, Kennett JP, Kennett DJ, Moore AMT, Hillman GC, Tankersley KB, Goodyear AC, Moore CR, Daniel IR, Ray JH, Lopinot NH, Ferraro D, Israde-Alcántara I, Bischoff JL, DeCarli PS, Hermes RE, Kloosterman JB, Revay Z, Howard GA, Kimbel DR, Kletetschka G, Nabelek L, Lipo CP, Sakai S, West A, Firestone RB (2013) Evidence for deposition of 10 million tonnes of impact spherules across four continents 12,800 y ago. Proc Natl Acad Sci 110:E2088-E2097. https://doi. org/10.1073/pnas.1301760110

Zöldföldi J, Pintér F, Székely B, Taubald H, Biró T, K., Mráv, Z., Tóth, M., Satir, M., Kasztovszky, Z., Szakmány, G. (2004) Római márványtöredékek vizsgálata a Magyar Nemzeti Múzeum gyûjteményéből. Archeometriai Múh I(1):16-22

Publisher's note Springer Nature remains neutral with regard to jurisdictional claims in published maps and institutional affiliations. 